OPEN ACCESS

Edited by:

Luca Gattinoni,

National Cancer Institute (NCl),

United States

Reviewed by:

Sema Kurtulus,

Novartis Institutes for BioMedical

Research, United States

Daniel E. Speiser,

Université de Lausanne, Switzerland

*Correspondence:

Xiao-Jie Lu

189@whu.edu.cn

Tailang Yin

reproductive@whu.edu.cn

†These authors have contributed equally to this work

Specialty section

This article was submitted to

Cancer Immunity and Immunotherapy,

a section of the journa

Frontiers in Immunology

Received: 20 May 2019

Accepted: 09 July 2019

Published: 19 July 2019

Citation:

Xia A, Zhang Y, XU J, Yin T and LU X-J (2019) T Cell Dysfunction in Cancer Immunity and Immunotherapy.

Front. Immunol. 10:1719. doi: 10.3389/fimmu.2019.01719

\section{T Cell Dysfunction in Cancer Immunity and Immunotherapy}

\author{
Anliang Xia ${ }^{1 t}$, Yan Zhang ${ }^{2 t}$, Jiang $\mathrm{Xu}^{3+}$, Tailang Yin ${ }^{4 *}$ and Xiao-Jie $\mathrm{Lu}^{1 *}$ \\ ${ }^{1}$ Department of General Surgery, Liver Transplantation Center, The First Affiliated Hospital of Nanjing Medical University, \\ Nanjing, China, ${ }^{2}$ Department of Clinical Laboratory, Renmin Hospital of Wuhan University, Wuhan, China, ${ }^{3}$ Department of \\ Rehabilitation, Huai'an Second People's Hospital, and the Affiliated Huai'an Hospital of Xuzhou Medical University, Huai'an, \\ China, ${ }^{4}$ Reproductive Medicine Center, Renmin Hospital of Wuhan University, Wuhan, China
}

In cancer, $\mathrm{T}$ cells become dysfunctional owing to persistent antigen exposure. Dysfunctional $T$ cells are characterized by reduced proliferative capacity, decreased effector function, and overexpression of multiple inhibitory receptors. Due to the presence of various inhibitory signals in the complex tumor microenvironment, tumor-specific $T$ cells have distinct dysfunction states. Therapeutic reactivation of tumor-specific $T$ cells has yielded good results in cancer patients. Here, we review the hallmarks of $T$ cell dysfunction in cancer. Also, we discuss the relationship between $T$ cell dysfunction and cancer immunotherapy.

Keywords: T cell dysfunction, immunity, cancer, immunotherapy, tumor microenvironment

\section{INTRODUCTION}

$\mathrm{T}$ cells can take part in a variety of immune responses that arise in various diseases, including infection, cancer, autoimmune diseases, and allergic diseases. In acute infections, naive $\mathrm{T}$ cells, upon antigen stimulation, are rapidly activated and differentiate into effector $\mathrm{T}$ cells (Teff). Teff differentiation involves transcriptional, epigenetic and metabolic reprogramming as well as the acquisition of effector features. After antigen clearance, most Teff die, but a small fraction of them differentiate into memory $\mathrm{T}$ cells, which quickly respond when the same antigen reappears (1). Memory T cells downregulate their effector program and own self-renewal ability driven by IL-7 and IL-15 in an antigen-independent manner (2). By contrast, during chronic infections and cancer, the function of $\mathrm{T}$ cells becomes compromised, termed $\mathrm{T}$ cell dysfunction, due to persistent antigen exposure (3-7). Previous studies have demonstrated that the severity of dysfunction is associated with the level of antigen stimulation (8,9). Furthermore, specific T cell receptor (TCR)-dependent pathways, for instance, those mediated by nuclear factor of activated T cells (NFAT) and sprouty homolog 2 (SPRY2), have been shown to be involved in T cell dysfunction, in line with the effects of ongoing TCR stimulation (10-12). In addition, chronic antigen stimulation also results in persistent expression of programmed cell death protein 1 (PD-1) by NFAT cytoplasmic 1 (NFATc1) (13). PD-1 may further regulate the level of TCR signaling $(14,15)$. Therefore, the extent and persistence of antigenic stimulation appear to be vital factors leading to $\mathrm{T}$ cell dysfunction and are associated with the severity of dysfunction. 
$\mathrm{T}$ cell exhaustion is a representative of $\mathrm{T}$ cell dysfunction. Exhausted $\mathrm{T}$ cells (Tex) differ from other dysfunctional $\mathrm{T}$ cells, including anergic $\mathrm{T}$ cells and senescent $\mathrm{T}$ cells (1618). Anergic $\mathrm{T}$ cells are induced by suboptimal stimulation, whereas senescent $\mathrm{T}$ cells enter a terminally differentiated state due to repeated stimulation, which involves irreversible cell cycle arrest and telomere shortening (Figure 1). In this article, we mainly discuss the exhausted $\mathrm{T}$ cells. $\mathrm{T}$ cell dysfunction was first discovered in mice infected with chronic lymphocytic choriomeningitis virus (LCMV), which is characterized by a progressive loss of function including proliferation, cytokine production and the ability to lyse target cells (3). Subsequently, $\mathrm{T}$ cell dysfunction was described in humans with chronic viral infections and cancer $(9,19-21)$. The acquired dysfunction was related to the co-expression of multiple inhibitory receptors (IRs) including PD-1, cytotoxic T lymphocyte antigen 4 (CTLA-4), T-cell immunoglobulin domain and mucin domain-3 (Tim-3), lymphocyte activation gene 3 (LAG-3), T cell immunoreceptor with Ig and ITIM domains (TIGIT), and others (4, 6, 9, 2225). Interestingly, studies in mice and humans have shown that dysfunctional $\mathrm{CD}^{+} \mathrm{T}$ cells coupregulate multiple IRs, and the type and amount of IRs are associated with the severity of the T cell dysfunction $(4,9,26,27)$. It is worth noting that dysfunctional $\mathrm{T}$ cells are not completely useless. Instead, these cells retain a certain level of residual function, and this residual function may be critical in vivo, limiting persistent pathogen infection and tumor progression. However, dysfunctional $\mathrm{T}$ cells fail to effectively eliminate infection and cancer.

Reversal of T cell dysfunction is becoming more important in improving immunity to cancer. Immune checkpoint blockade, as one modality of cancer immunotherapy, is designed to enhance $\mathrm{T}$ cell function and thus exert an effective anti-tumor $\mathrm{T}$ cell response $(28,29)$. One of the major markers of $\mathrm{T}$ cell dysfunction is the overexpression of PD-1. Blocking PD-1 or its ligand PD-L1 successfully reactivates $\mathrm{T}$ cell function, emphasizing the importance of the PD-1/PD-L1 axis in reversing $\mathrm{T}$ cell dysfunction (22). Encouraging results have been observed in a variety of cancer types, such as melanoma, urothelial cancer and non-small-cell lung cancer (NSCLC), with the use of antibodies targeting PD-1/PD-L1 (30-33). However, most patients do not maintain sustained responses to this therapy. The lack of a longlasting response may be partly explained by the presence of other inhibitory receptors in $\mathrm{T}$ cells.

Here, we review the hallmarks of $\mathrm{T}$ cell dysfunction in cancer. Also, we discuss the relationship between $\mathrm{T}$ cell dysfunction and cancer immunotherapy.

\section{TRAITS AND MECHANISMS OF T CELL DYSFUNCTION IN CANCER}

\section{Inhibitory Receptors in Dysfunctional T Cells}

One of the traits of dysfunctional $\mathrm{T}$ cells is the increased and sustained expression of multiple inhibitory receptors, including PD-1, CTLA-4, Tim-3, and LAG-3 (Figure 3a). In general, the number of inhibitory receptors expressed by dysfunctional
$\mathrm{T}$ cells is positively associated with $\mathrm{T}$ cell dysfunction. In other words, the greater the number, the more serious the dysfunction. Additionally, functional effector $\mathrm{T}$ cells can transiently express inhibitory receptors upon activation. For instance, $\mathrm{PD}$ - 1 expression rapidly increases after $\mathrm{T}$ cell activation and may remain at moderate levels in healthy individuals $(34,35)$. To control autoreactivity and immunopathology, inhibitory receptors play a key negative regulatory role (36). In healthy adults, for example, circulating $\mathrm{PD}-1^{+} \mathrm{CD} 8^{+} \mathrm{T}$ cells are not representative of dysfunctional $\mathrm{T}$ cells, but instead are representative of effector memory cells (35). In addition, IR expression patterns in dysfunctional $\mathrm{T}$ cells also have differences between cancer and infection, albeit with many common features (5). B- and T-lymphocyte attenuator (BTLA) is upregulated in dysfunctional $\mathrm{CD}^{+} \mathrm{T}$ cells in cancer, but is absent in dysfunctional CD8 ${ }^{+}$T cells in $\operatorname{LCMV}(4,27)$. This finding shows that the molecular mechanisms that cause IR upregulation and $\mathrm{T}$ cell dysfunction may be somewhat different between chronic infections and cancer.

Moreover, each IR binds to its ligand, which is typically expressed by antigen presenting cells (APCs) and tumor cells in the tumor microenvironment (TME), to affect T cell survival, proliferation and function (Figure 2). In view of this, the availability and amount of ligands in the TME is critical for IR to play a negative regulatory role in $\mathrm{CD}^{+} \mathrm{T}$ cells. As one of the ligands for PD-1, the expression of PD-L1 in the TME relies on exposure to inflammatory cytokines (37). Conversely, CD155 and CD112, as TIGIT ligands, are continuously expressed in the TME by most melanoma cells and APCs (25). In addition, Tim-3 directly binds to Galectin-9 and CEACAM1 to inhibit T cell function $(38,39)$. Also, Tim3 can bind to phosphatidylserine and the DNA binding protein HMGB1 $(40,41)$.

The molecular mechanisms of IR-mediated immunomodulation of $\mathrm{T}$ cells have not been fully elucidated. There are several possible mechanisms to support IR-mediated immune regulation. First, IR competes with costimulatory receptors for binding to its ligand to prevent the formation of microclusters and lipid rafts (25). For instance, CTLA-4 can compete with the costimulatory molecule CD28 to bind to CD80 and CD86 (42), while TIGIT can compete with CD226 to bind to the same ligands CD112 and CD155 $(43,44)$. The imbalance in the expression levels of IR and costimulatory receptors affects the same ligand binding (45). In patients with metastatic melanoma, $\mathrm{CD} 8^{+}$TILs upregulate TIGIT and downregulate CD226, leading to an imbalance of TIGIT/CD226 expression (25). This imbalance may be conducive to inhibiting $\mathrm{T}$ cell responses to tumors in the TME, besides $\mathrm{T}$ cell inhibition mediated by TIGIT itself (46). Second, activation of T cells by TCR or costimulatory receptors is disrupted by negative signals mediated by PD- 1 and CTLA- $4(45,47)$. When TIGIT/CD155 is ligated, APCs produce IL-10, which also inhibits $\mathrm{T}$ cell function (44). In addition, CD28 can also be expressed by $\mathrm{PD}-1^{+} \mathrm{T}$ cells. CD28, as a costimulatory molecule, stimulates the activation of naive $\mathrm{T}$ cells and promotes cytokine secretion. Recent studies have revealed that the PD-1/PD-L1 axis inhibits $\mathrm{T}$ cell function through inactivation of CD28 signaling (48). 
Anergic T cells

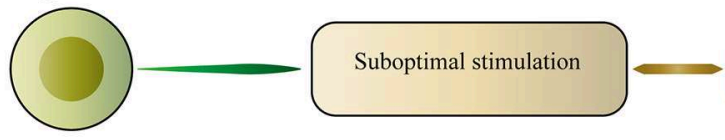

\section{Features}

Low proliferative capacity None or low effector function

\section{Exhausted T cells}

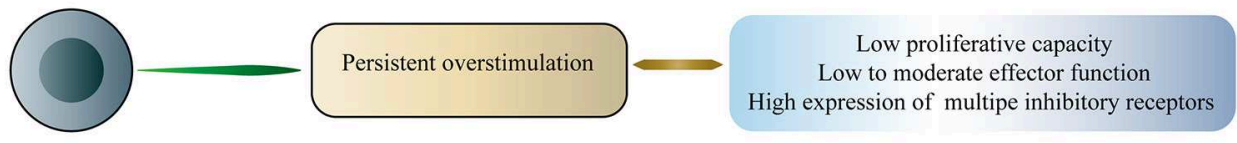

\section{Senescent T cells

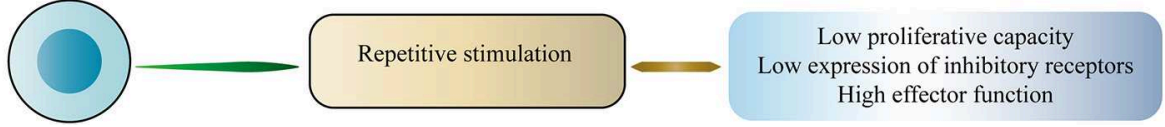

FIGURE 1 | Classification of dysfunctional T cells.

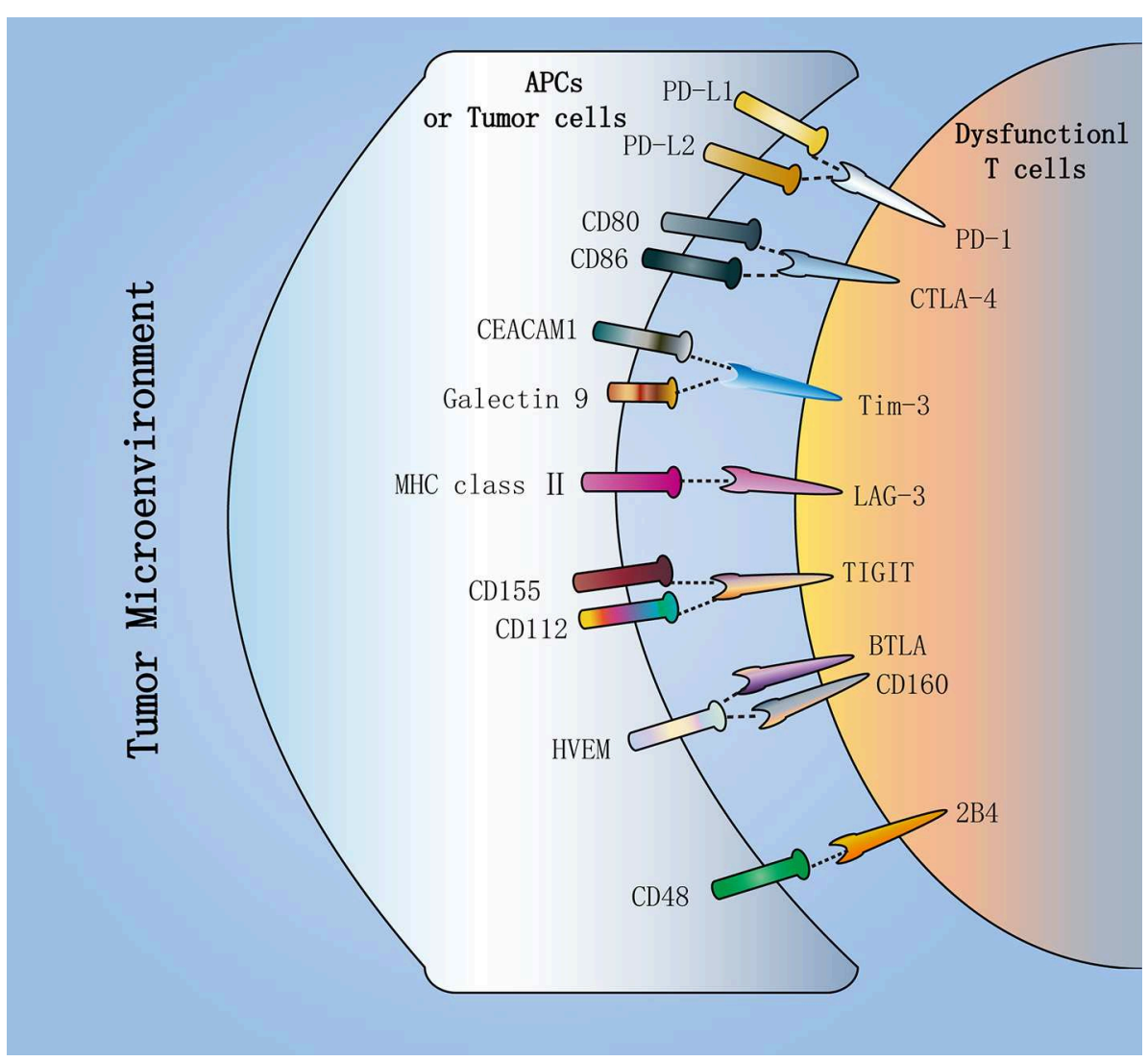

FIGURE 2 | Inhibitory receptors in dysfunctional T cells. Dysfunctional T cells in the tumor microenvironment (TME) express multiple inhibitory receptors, including PD-1, CTLA-4, Tim-3, LAG-3, and TIGIT. They bind to their respective ligands, which are typically expressed by antigen-presenting cells (APCs) or tumor cells in the TME. PD-1, as the major inhibitory receptor, has two ligands PD-L1 and PD-L2. CTLA-4 can compete with the costimulatory molecule CD28 to bind to CD80 and CD86. Additionally, TIGIT can compete with CD226 to bind to CD112 and CD155. In addition, Tim-3 directly binds to Galectin-9 and CEACAM1 to inhibit T cell function. These inhibitory receptors contribute to $T$ cell dysfunction in cancer. 


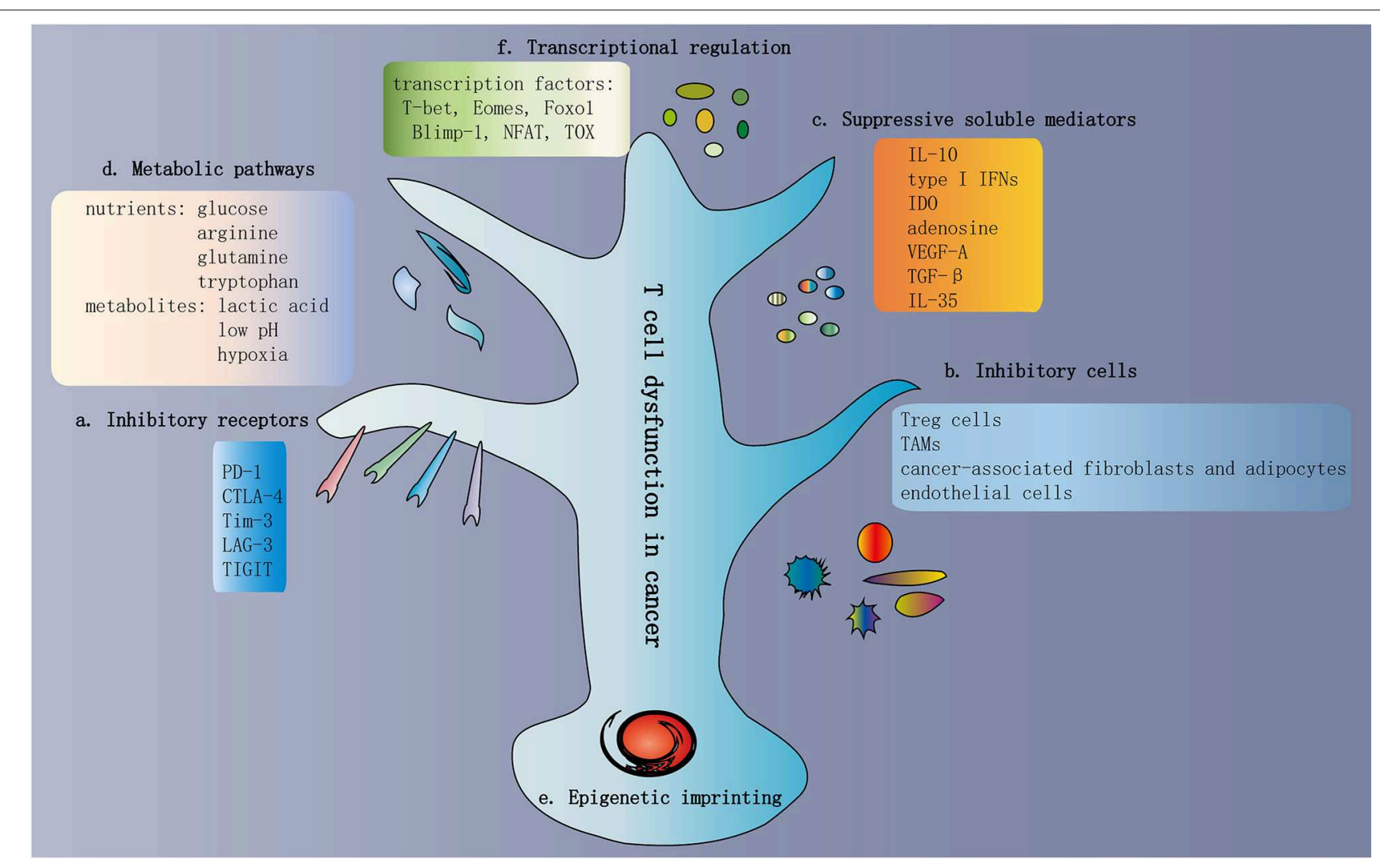

FIGURE 3 | Traits of T cell dysfunction in cancer. (a) Inhibitory receptors in dysfunctional T cells. One of the traits of dysfunctional T cells is the increased and sustained expression of multiple inhibitory receptors, including PD-1, CTLA-4, Tim-3, LAG-3, and TIGIT. In general, the greater the number of inhibitory receptors coexpressed by dysfunctional T cells, the more severe the dysfunction. (b) Inhibitory cells in the TME. The TME contains various cell types involved in multiple biological processes that promote or inhibit tumor progression. Immunosuppressive cells are present in the TME, which contribute to T cell dysfunction. These inhibitory cells include Treg cells, TAMs, MDSCs, cancer-associated fibroblasts and adipocytes, and endothelial cells. (c) Suppressive soluble mediators. Some soluble molecules exist in the TME and mediate T cell dysfunction. These molecules include IL-10, type I IFNs, IDO, adenosine, VEGF-A, TGF- $\beta$, and IL-35. (d) Metabolic pathways in the TME. The activation of T cells and the exertion of antitumor immunity depend on some common metabolic pathways, such as aerobic glycolysis, amino acid metabolism, glutaminolysis, and de novo fatty acid synthesis. These metabolic pathways are also important preconditions for cancer cell proliferation and survival. Hence, within the TME, T cells compete with cancer cells to obtain adequate nutrients. In addition to nutrients, various metabolites are also involved in T cell dysfunction, such as lactic acid, low pH, and hypoxia. (e) Epigenetic imprinting of T cell dysfunction. Epigenetic imprinting of dysfunctional T cells differs from that of effector/memory T cells. Persistent PDCD1 demethylation and unique changes in chromatin accessibility occur in dysfunctional T cells. (f) Transcriptional regulation of $\mathrm{T}$ cell dysfunction. Transcriptional regulation of $\mathrm{T}$ cell dysfunction involves changes in the expression patterns and transcriptional connection of some important transcription factors, such as T-bet, Eomes, Foxo1, Blimp-1, NFAT, and TOX. TME, tumor microenvironment; Treg cells, regulatory T cells; TAMs, tumor-associated macrophages; MDSCs, myeloid-derived suppressor cells; IDO, indoleamine 2,3 -dioxygenase; TGF- $\beta$, transforming growth factor- $\beta$.

In a mouse model, conditional knockout of CD28 abolishes the effects of PD-1 blockade (49). This suggests that the CD28/B7 pathway may act as an important role in the efficacy of anti-PD-1 therapy.

Accumulated evidence shows that simultaneous blockade of multiple inhibitory receptors is more effective than single IR blockade in reversing dysfunctional $\mathrm{CD} 8^{+} \mathrm{T}$ cells in vitro and in vivo. For example, blockade of PD-1 combined with blockade of CTLA-4, Tim-3, LAG-3, or TIGIT blockade, to some extent, can reverse $\mathrm{T}$ cell dysfunction and enhance antitumor immunity $(23,25,26,50,51)$. These inhibitory receptor molecules are derived from different structural families and have different intracellular signaling domains. They can bind to ligands with different expression patterns.

\section{Inhibitory Cells in the Tumor Microenvironment (TME)}

The TME contains a variety of cell types that participate in various biological processes, which promote or inhibit tumor progression. Immunosuppressive cells are present in the TME and contribute to $\mathrm{T}$ cell dysfunction. These inhibitory cells include regulatory $\mathrm{T}$ cells (Treg cells), tumor-associated macrophages (TAMs), myeloid-derived suppressor cells (MDSCs), cancer-associated fibroblasts and adipocytes, and endothelial cells (Figure 3b).

Treg cells, as a major group of infiltrating $\mathrm{CD} 4^{+} \mathrm{T}$ cells in the TME, can significantly inhibit the antitumor immunity mediated by $\mathrm{T}$ cells $(52,53)$. Treg cells usually disrupt the activation, proliferation, and survival of effector $\mathrm{T}$ cells by producing 
immunosuppressive molecules, including transforming growth factor- $\beta$ (TGF- $\beta$ ) and interleukin-10 (IL-10) $(6,54)$. Notably, multiple IRs are upregulated in highly inhibitory Treg cells, including PD-1, CTLA-4, Tim-3, and TIGIT (55-57). Of course, they also upregulate molecules associated with $\mathrm{T}$ cell dysfunction or trafficking, including CCR4, CD39, and CD73, as well as members of the TNF receptor superfamily, such as GITR and OX40 (58-60). Therefore, antibodies targeting CTLA-4, CCR4, and/or GITR on Treg cells can deplete Treg cells, reverse T cell dysfunction, and restore $\mathrm{T}$ cell antitumor immunity and immune surveillance on cancer cells (61-63).

TAMs suppress $\mathrm{T}$ cell antitumor immunity and promote tumor development, involving functions such as the sustained accumulation of Treg cells and dysregulation of the vasculature due to the expression of chemokines and amino acid-degrading enzymes, such as arginase 1 and indoleamine-2,3-dioxygenase (IDO) (64-66). Similarly, MDSCs enter TME aberrantly, produce nitric oxide and reactive oxygen species, and express arginase 1 and IDO, thereby effectively promoting $\mathrm{T}$ cell dysfunction $(67,68)$. In a mouse model, targeting MDSCs with monoclonal antibodies has been demonstrated to restore the antitumor immune responses and tumor killing ability of tumor-infiltrating T lymphocytes (TILs) (69).

Cancer-associated fibroblasts can secrete cytokines and chemokines, and disrupt the deposition of the extracellular matrix, which shapes the structure of the TME and thus contributes to tumorigenesis $(70,71)$. T cell dysfunction can also be caused by cancer-associated fibroblasts via the production of TGF- $\beta$ and vascular endothelial growth factor (VEGF) (72, 73). Moreover, recent findings have also shown that cancerassociated adipocytes impair antitumor immunity and promote tumor malignancy in several cancers (74-76). The mechanism may be mediated by the metabolic and paracrine regulation of tumor infiltrating immune cells and cancer cells.

Endothelial cells may promote $\mathrm{T}$ cell dysfunction by improving the production of prostaglandin E2 (PGE2) and CD95L, while impairing $\mathrm{T}$ cell recruitment by reducing the expression of vascular cell adhesion molecule 1 (VCAM1) (7779). The underlying mechanisms of these changes are mediated by hypoxia and VEGF signaling in endothelial cells. In addition, metabolic communication between cancer and endothelial cells, as well as lymphatic endothelial cells, may help impede antitumor $\mathrm{T}$ cells and mediate immunosuppression (80-82).

\section{Suppressive Soluble Mediators}

Some soluble molecules are present in the TME that mediate $\mathrm{T}$ cell dysfunction. These molecules include IL-10, type I IFNs, IDO, adenosine, VEGF-A, TGF- $\beta$, and IL-35 (Figure 3c).

IL-10 is produced by various immune cells and serves as an effective antiinflammatory molecule (83). For instance, natural killer cells, APCs, T cells, and B cells can generate IL-10 (84-87). Interestingly, the dose of IL-10 and the state of T cell activation can affect the effects of IL-10 on T cells in vivo (88). On the one hand, IL-10 impairs antitumor immunity and promotes tumor growth in mouse models (89). Simultaneous blockade of PD-1 and IL-10 results in increased survival and delays tumor growth in ovarian cancer, leading to an enhanced antitumor immune response and reduced infiltration of immunosuppressive MDSCs (90). On the other hand, high doses of IL-10 and PEGylated IL10 hamper the progression of tumors in animals and increase the expansion and function of $\mathrm{CD}^{+}$TILs expressing elevated IL-10R $(88,91)$. Thus, IL-10 may have a paradoxical effect on T cells in vivo.

Type I IFNs including IFN $\alpha$ and IFN $\beta$ may be typical cytokines with a dual role. As key pro-inflammatory cytokines, type I IFNs inhibit viral replication by directly inducing antiviral activity and activating innate immune cells (92). Additionally, type I IFN signaling facilitates the optimal priming of $\mathrm{T}$ cells and production of functional effector $\mathrm{T}$ cells and memory $\mathrm{T}$ cells (93). However, some studies have also shown that IFN $\alpha$ promotes the persistence of viruses in chronic infections and induces $\mathrm{T}$ cell dysfunction (94). During the first few days of LCMV infections, blockade of IFN $\alpha$ can effectively prevent the occurrence of $\mathrm{T}$ cell dysfunction (94). The mechanism by which IFN $\alpha$ promotes $\mathrm{T}$ cell dysfunction may be through the production of immunosuppressive molecules, such as IL-10, PDL1, and IDO, as well as the stimulation and maintenance of PD-1 expression on T cells (95). Notably, IFN $\alpha$ blockade combined with PD-1 blockade effectively enhances antitumor immune responses in tumor-bearing mice (95).

IDO is expressed by tumor cells, APCs and CD8 ${ }^{+} \mathrm{T}$ cells in the TME (96-99). IDO activates Tregs by producing kynurenine and inhibits $\mathrm{T}$ cell function by depleting the essential amino acid tryptophan (100). In addition, resistance to anti-PD-1 and anti-CTLA-4 mAbs is closely related to IDO (101). Adenosine exerts an inhibitory role and directly impedes effector $\mathrm{T}$ cell function by activating the adenosine receptor A2aR (102). Indirect destruction of effector $\mathrm{T}$ cell function is induced by increased Treg function, decreased APC activation, and MDSC induction (103). Moreover, VEGF-A is generated by tumor cells in the TME. In addition to its proangiogenic properties, VEGFA inhibits dendritic cell maturation, increases the accumulation of MDSCs and induces Tregs, all of which contribute to the formation of an immunosuppressive TME milieu (104, 105). Coexpression of various IRs is increased by VEGF-A in a VEGFR2- and NFAT-dependent manner, including PD-1, CTLA-4, and Tim-3 (106). In addition, TGF- $\beta$ is involved in T cell dysfunction in cancer (107). TGF- $\beta$ inhibits antitumor immunity and shapes the TME by impeding T cell infiltration (108).

IL-35 is expressed by activated Treg cells and regulatory B cells (109-111). A recent study showed that Treg-derived IL-35 could promote T cell exhaustion (112). The underlying mechanism was direct regulation of Blimp1 expression in $\mathrm{CD}^{+}$ $T$ cells, increased IR expression and restricted differentiation of central memory $\mathrm{CD}^{+}{ }^{+} \mathrm{T}$ cells (112). In addition, neutralization of IL-35 promotes $\mathrm{CD}^{+}$TIL proliferation and production of inflammatory cytokines (113). Neutralization of IL-35 also decreases tumor growth in a mouse tumor model (113). These results indicate that IL-35 favors the immunosuppressive TME.

\section{Metabolic Pathways in the TME}

The activation of $\mathrm{T}$ cells and exertion of antitumor immunity depend on some common metabolic pathways, such as aerobic glycolysis, amino acid metabolism, glutaminolysis and de novo 
fatty acid synthesis (114). These metabolic pathways are also important for cancer cell proliferation and survival. Hence, within the TME, T cells compete with cancer cells to obtain adequate nutrients (Figure 3d).

Recently, some studies have demonstrated that cancer cells compete with TILs to acquire the essential glucose, which results in less availability of glucose to T cells (115). The reduction or deprivation of glucose induces $\mathrm{T}$ cell dysfunction and impairs the immune response $(116,117)$. Therefore, restraining the metabolic activity of tumor cells may have potential value in increasing the amount of glucose available to $\mathrm{T}$ cells, thereby improving the antitumor activity of T cells. Moreover, glycolysis is required for $\mathrm{T}$ cell maturation, expansion and effector function $(114,118)$. The CD28 signaling pathway can facilitate the transition of T cell metabolism to glycolysis. Therefore, both PD1 and CTLA- 4 can restrict T cell glycolysis by interfering with CD28 signaling. Compared to CTLA-4, PD-1 can also induce the fatty acid $\beta$-oxidation (FAO) rate-limiting enzyme carnitine palmitoyl transferase (Cptla) to simultaneously promote FAO (119). Notably, the role of PD-1 in inducing FAO relies on the simultaneous inhibition of the PI3K/AKT and MEK/ERK signaling pathways, which regulate glucose metabolism (119). Blocking PD-1 or CTLA-4 restores the glycolytic ability of TILs in a mouse model, which promotes glycolysis in $\mathrm{T}$ cells (115). It is noteworthy that PD-L1 derived from tumor cells can facilitate tumor glycolysis through AKT/mTOR signaling (115). Thus, blocking the PD-1/PD-L1 axis can lead to a range of synergistic antitumor effects: restoring tumor-specific $\mathrm{T}$ cell function, reducing tumor glycolysis, and improving glucose availability to $\mathrm{T}$ cells in the TME.

Of course, certain amino acids, including arginine, glutamine and tryptophan, are also important nutrients that stimulate $\mathrm{T}$ cell activation and promote cancer cell proliferation and survival. For instance, arginine is a nutrient necessary for $\mathrm{T}$ cell activation and proliferation (120). TAMs and MDSCs express arginase 1, which decomposes and reduces arginine in the TME, and results in impaired effector $\mathrm{T}$ cell function (121-123). Interestingly, for $\mathrm{T}$ cell activation and differentiation, glutamine is essential (124). However, cancer cells exert a strong intake of glutamine, which is conducive to tumor development (125). It is well known that the rate-limiting enzyme for glutamine decomposition is glutaminase. In a mouse model, targeting glutaminase is effective in controlling tumor occurrence (126). Therefore, we can infer that excessive glutaminolysis in the TME is due to cancer cells, which restricts the utilization of glutamine by $\mathrm{T}$ cells and thereby promotes T cell dysfunction. Moreover, because tumor cells and suppressive immune cells secrete the tryptophan metabolism enzyme IDO, tryptophan is catabolized into kynurenine, an immunosuppressive metabolite (127). Accumulated kynurenine facilitates regulatory $\mathrm{T}$ cell production (128). Collectively, these results indicate that in the TME, T cells can effectively exert antitumor immunity, which is inseparable from some important nutrients. These essential nutrients may be controlled by cancer cells and immune regulatory cells.

In addition to nutrients, various metabolites are also involved in $\mathrm{T}$ cell dysfunction, such as lactic acid, low $\mathrm{pH}$, and hypoxia (Figure 3d). Tumor-derived lactic acid can induce apoptosis in naive $\mathrm{T}$ cells, which may support tumor immune escape, due to the loss of the $200 \mathrm{kDa}$ FAK family interacting protein (129). Lactic acid induces $\mathrm{pH}$ alterations and a loss of cytosolic $\mathrm{NAD}^{+}$ regeneration, which further limits $\mathrm{T}$ cell activity and cytokine production (130). Thus, neutralizing acidic components in the TME may contribute to enhancing T cell antitumor immunity (131). Notably, hypoxia is another metabolic parameter in the TME due to rapid tumor growth. Different studies have shown that hypoxia improves or impairs $\mathrm{T}$ cell immune responses. In murine chronic infections and tumor models, results indicate that hypoxia can enhance the cytotoxic function of T cells as well as lead to more effective viral and tumor control $(132,133)$. By contrast, increased expression and activity of the transcription factor hypoxia-inducible factor $1 \alpha$ (HIF-1 $\alpha$ ) is induced by hypoxia, which increases the expression of inhibitory receptors on T cells and reduces T cell effector function $(132,134)$.

\section{Epigenetic Imprinting of T Cell Dysfunction}

The epigenetic imprinting of dysfunctional $\mathrm{T}$ cells differs from that of effector/memory T cells (Figure 3e). Normally, PDCD1 (encoding PD-1) is temporarily demethylated in activated T cells, after which normal methylation levels are restored. In chronic viral infections, results indicate that the PDCD1 demethylation levels persist in activated $\mathrm{T}$ cells, leading to long-term expression of PD-1 and T cell dysfunction (135-137). Even after the virus is cleared to levels that cannot be detected by current technologies, this demethylation pattern of the PDCD1 locus is still sustained, suggesting that this epigenetic program has been fixed. Interestingly, one study reported the presence of two T cell clones with different affinities in Melan-A-specific TILs in human melanoma (138). Low avidity $\mathrm{T}$ cell clones, due to the sustained methylation of the PDCD1 promoter, do not express PD-1 even when stimulated by TCR. Conversely, antigen-specific T cells with high functional avidity express PD-1. These phenomena suggest a relationship among expression of PD-1, modification of the PDCD1 locus and intensity of TCR signaling (138). Aside from the continued demethylation of the PDCD1 locus, dysfunctional $\mathrm{T}$ cells gradually undergo de novo methylation of genes involved in effector functions during persistent infections and tumor progression, limiting $\mathrm{T}$ cell expansion and clonal diversity (139). This cannot be reversed by PD-1 blockade. However, during PD-1 blockade, blocking dysfunction-related methylation imprinting has a synergistic effect in a murine tumor model, as manifested by increased $\mathrm{T}$ cell immune responses and tumor control (139).

In addition, unique changes in chromatin accessibility occur in dysfunctional $\mathrm{T}$ cells. For example, in chronic LCMV infection, additional accessible regions of PDCD1 appeared in dysfunctional T cells (140). However, some open regions of the IFNG locus were present in functional $\mathrm{T}$ cells and were absent in dysfunctional $\mathrm{T}$ cells. It is worth noting that after anti-PD1 treatment, these accessible areas specific to the dysfunctional state did not significantly change, showing that the epigenetic program was only minimally remodeled (141). Similarly, tumor antigen-specific and bystander T cells were adoptively transferred in a murine tumor model (142). Gene expression and chromatin accessibility were then compared. The results showed that only 
tumor-specific $\mathrm{T}$ cells were characterized by dysfunction and exhibited increased effector functions after anti-PD-L1 therapy, with little change in chromatin accessibility (142).

Moreover, epigenetic imprinting begins in the early stages of dysfunction. Many changes in dysfunctional T cells in advanced tumors of mouse liver cancer models are also present in T cells from precancerous lesions (7). Two different chromatin states can mirror the process of moving from mild dysfunction in early tumor lesions to more severe dysfunction in late-stage tumors. On the one hand, the chromatin state of early dysfunctional TILs shows partial plasticity and can be reprogrammed by anti-PD-1 therapy. On the other hand, the advanced state is fixed and cannot be changed by anti-PD-1 therapy (143). It is noteworthy that most of the overlap exists between the chromatin accessibility state of $\mathrm{PD}-1^{\text {hi }} \mathrm{CD} 8^{+}$TILs from human non-smallcell lung cancer and the chromatin accessibility state of late TILs in mice. Thus, PD-1/PD-L1 blockade in human tumors may only cause transcriptional rewiring rather than altering the chromatin accessibility pattern itself.

\section{Transcriptional Regulation of T Cell Dysfunction}

Transcriptional regulation of $\mathrm{T}$ cell dysfunction involves changes in the expression patterns and transcriptional connection of some important transcription factors. Some transcription factors are expressed in both functional Teff and dysfunctional $\mathrm{T}$ cells (Figure 3f). However, in dysfunctional T cells, these transcription factors are linked to different genes and transcriptional loops, showing activity in specific contexts $(144,145)$.

T-bet and Eomes, as T-box family transcription factors, play a crucial role in the development of effector and memory $\mathrm{CD} 8^{+} \mathrm{T}$ cells $(146,147)$. In acute infection, T-bet promotes the formation of Teff cells and the development of KLRG-1 ${ }^{+}$terminal Teff cells, while Eomes promotes the expression of IL-15R $\beta$ and the development of memory $\mathrm{T}$ cells in a homeostatic manner (2, 144, 147-149). However, in chronic infection, the role of Tbet and Eomes is different from their function in Teff and Tmem cells (145). For example, the formation of a dysfunctional $\mathrm{T}$ cell population requires the participation of both T-bet and Eomes. And if either transcription factor is genetically deleted, the dysfunctional $\mathrm{T}$ cell population cannot form (144). Furthermore, due to its potential ability to inhibit the transcription of the IR genes (e.g., Pdcd1 encoding PD-1), upregulated expression of T-bet favors the formation of progenitor PD- $1^{\text {int }}$ Eomes ${ }^{\text {lo }}$ Tex subpopulation (144). As for Eomes, its high expression in the terminal Tex subpopulation differs from that in the selfrenewal Tmem cells in acute infection (144). In view of this, transcriptional network analysis is performed, and it has been shown that Eomes participates in almost completely different transcription networks in functional Teff and Tmem cells compared with Tex cells (145). Therefore, the functions of T-bet and Eomes are rewiring in Tex cells.

Other transcription factors are also involved in $\mathrm{T}$ cell dysfunction. Foxo1, Blimp-1, NFAT, IRF-4, and BATF can promote or antagonize $\mathrm{T}$ cell dysfunction by modulating dysfunction or effector-specific genes, respectively (12, 150-154).
The expression level of these transcription factors directly affects their capability of driving distinct transcriptional programs. For instance, dysfunctional $\mathrm{T}$ cells upregulate Foxo1 and Blimp1 , which act as positive regulators of $\mathrm{T}$ cell dysfunction (150, 152, 155). Also, metabolic-related transcription factors, including hypoxia-inducible factor (HIFs) and von Hippel-Lindau (VHL) complexes, may promote $\mathrm{T}$ cell dysfunction in some cases (156). In addition, recent research has found that TOX, as a new transcription factor, promotes $\mathrm{T}$ cell dysfunction in cancer (157-159).

\section{HETEROGENEITY IN DYSFUNCTIONAL T CELLS}

Dysfunctional T cells are heterogeneous. Firstly, PD-1 and CD44 are utilized to distinguish subpopulations of dysfunctional T cells with various biological functions. Studies have revealed that PD$1^{\text {int }} \mathrm{CD} 44^{\text {hi }} \mathrm{T}$ cells had a lower degree of dysfunction than PD$1^{\text {hi }} \mathrm{CD} 44^{\text {int }} \mathrm{T}$ cells, which may be partially explained by lower coexpression of IRs (9). Furthermore, the PD- ${ }^{\text {int }} \mathrm{T}$ cells can produce a therapeutic response to $\mathrm{PD}-1$ blockade. Conversely, $\mathrm{PD}-1{ }^{\text {hi }} \mathrm{CD} 44^{\text {int }} \mathrm{T}$ cells are in a terminally dysfunctional state and have no therapeutic response to immune checkpoint blockade (9). Subsequent studies have also shown that the PD- ${ }^{\text {int }} C D 44^{\text {hi }}$ T cell subpopulation is mainly composed of T-bet ${ }^{\text {hi }}$ and Eomes ${ }^{\text {lo }}$ cells, and as a progenitor cell population, can persistently generate $\mathrm{PD}-\mathrm{1}^{\text {hi }} \mathrm{CD} 44^{\text {int }}$ Eomes ${ }^{\text {hi }} \mathrm{T}$ cell population with terminal dysfunction state (144).

In addition, the understanding of dysfunctional $\mathrm{T}$ cell heterogeneity is further improved due to the recognized role of CXCR 5 and the transcription factor Tcf- 1 . The CXCR $5^{+}$Tcf$1^{+}$Tim $-3^{-}$T cell subpopulation can respond to PD-1 blockade and produce a more terminal $\mathrm{CXCR} 5^{-} \mathrm{Tcf}-1^{-} \mathrm{Tim}-3^{+} \mathrm{T}$ cell subpopulation (160). Interestingly, there is no difference in the expression of the transcription factors T-bet and Eomes between the two subpopulations (160). These results may reveal the heterogeneity in the original PD- $1^{\text {int }}$ progenitor cell populations.

Therefore, the heterogeneity of dysfunctional $\mathrm{T}$ cells is complex. Identifying progenitor populations that respond to checkpoint blockade may be more beneficial to the development of cancer immunotherapy and to cancer patients.

\section{REVERSAL OF DYSFUNCTIONAL T CELLS BY IMMUNOTHERAPY}

\section{Single or Combined Immune Checkpoint Blockade}

Immunotherapy for treating tumor-induced $\mathrm{T}$ cell dysfunction has provided hope to patients with cancer. Currently, immunotherapy has focused on blocking immune checkpoints in patients with various solid and hematological tumors (161-164). The most commonly targeted immune checkpoints are PD-1 and CTLA-4. Generally, PD-1 impedes T cell function by interfering with $\mathrm{T}$ cell receptor (TCR) signaling, whereas CTLA-4 impedes $\mathrm{T}$ cell function by competing with the costimulatory molecule CD28 to bind to CD80/CD86 $(165,166)$. Since Treg cells also 
express CTLA-4, antibodies targeting CTLA-4 can inhibit Treg cell function or enhance antitumor immunity by selectively eliminating Treg cells in a mouse model (62). The CTLA-4 targeting agent, ipilimumab, was the first immune checkpoint inhibitor. With the use of ipilimumab, overall survival was significantly increased in patients with advanced melanoma $(167,168)$. Of note, in patients with melanoma treated with anti-CTLA-4, the melanoma-reactive $\mathrm{CD} 8^{+} \mathrm{T}$ cell response in peripheral blood was found to be significantly increased (169). This result suggests that enhanced $\mathrm{T}$ cell priming also plays a role. Also, PD-1 pathway blockade can effectively reverse dysfunctional $\mathrm{T}$ cells and increase antitumor activity in patients with various cancers, especially in viral infection-driven cancers or carcinogen-induced cancers (170-174). In addition, as mentioned above, recent studies have revealed that the PD1/PD-L1 axis inhibits T cell function through the inactivation of CD28 signaling instead of TCR signaling (48). In a mouse model, conditional knockout of CD28 abolished the effects of PD-1 blockade (49), suggesting that the CD28/B7 pathway may act as an important role in the efficacy of anti-PD-1 therapy. Currently, five anti-PD-1 or anti-PD-L1 antibodies have been approved by the FDA for the treatment of a variety of cancers, including hepatocellular carcinoma, renal cell carcinoma and Hodgkin's disease (175).

Moreover, compared with monotherapy, the combined use of anti-CTLA-4 and anti-PD-1 has demonstrated prolonged progression-free survival and significant tumor regression in clinical trials of cancer patients $(176,177)$. Also, PD-1 blockade combined with other checkpoint blockades, such as Tim-3, LAG-3, or TIGIT, significantly reverses $\mathrm{T}$ cell dysfunction and enhances antitumor immunity in patients with cancer, compared to individual checkpoint blockade $(25,26,178,179)$. At present, humanized anti-TIM3 (TSR-022), anti-LAG3 (MK4280), and anti-TIGIT (BMS-986207) antibodies against various cancers are under clinical trials. However, the underlying precise mechanisms to explain the efficacy of immune checkpoint blockade have not been fully described.

\section{Immune Checkpoint Blockade in Combination With Other Immunotherapies}

The combination of inhibitory receptor blockade and costimulatory molecule targeting exerts a synergistic effect in re-activating tumor-specific T cells. CD137 (or 4-1BB), a member of the TNFR family, is expressed on activated T cells (180). In a murine model, the combination of agonistic antiCD137 antibodies and PD-1 blockade effectively controls tumor growth (181). This combination therapy also improves the $\mathrm{T}$ cell response to tumor antigens and promotes effector/memory $\mathrm{CD}^{+} \mathrm{T}$ cell formation (182). Another member of the TNFR family, OX40, is primarily expressed on activated CD4 ${ }^{+} \mathrm{T}$ cells. And its expression on $\mathrm{CD}^{+} \mathrm{T}$ cells is at a lower level upon TCR triggering (183). The research results show that OX40 agonists play an antitumor immunity-promoting role in immunogenic mouse tumor models, but do not play an effective role in tumor control in a poor immunogenic tumor model $(184,185)$. Strikingly, in a vaccination setting, the addition of PD-1 blockade to OX40 agonists virtually eliminates the antitumor effect of OX40 monotherapy due to the reduced TIL infiltration and enhanced cell death of tumor-reactive $\mathrm{CD}^{+} \mathrm{T}$ cells (186). This effect deserves close attention because it is uncertain whether a similar harmful effect will occur in human cancers. Also, this phenomenon underscores the importance of the timing of different immunotherapeutic interventions to avoid the negative effects of $\mathrm{T}$ cell overstimulation.

Furthermore, anti-CTLA-4 therapy in combination with anti-VEGF antibodies has been shown to increase antitumor immune responses and achieve encouraging clinical results in patients with metastatic melanoma (187). Moreover, in mice with melanoma, researchers have demonstrated that the use of PPAR $\alpha$ agonists can promote fatty acid catabolism in vaccine-induced $\mathrm{CD}^{+}$TILs. The addition of anti-PD-1 antibodies obviously enhanced the antitumor efficacy (188).

Therefore, future research should focus on how combination therapies should be applied and which dysfunctional states may be best for them.

\section{CAR-T Cell Therapy}

A CAR-T cell is genetically modified to express an antigenspecific, non-MHC restricted receptor, which consists of the single-chain variable fragment $(\mathrm{scFv})$ of an antibody, a transmembrane domain and an intracellular signaling domain (189, 190). Thus far, CAR-T cell therapy has achieved great success in treating hematological malignancies (191, 192). However, some patients still lack response and relapse after receiving CAR-T treatment, possibly due to the poor proliferative capacity and the short duration of $\mathrm{T}$ cells. Therefore, a transcriptomic analysis was conducted to compare $\mathrm{T}$ cells from chronic lymphocytic leukemia (CLL) responders and nonresponders after CAR-T treatment (193). The results showed that $\mathrm{T}$ cells from non-responders upregulated pathways associated with exhaustion and apoptosis compared to $\mathrm{T}$ cells from responders (193). Inhibitory receptors were also upregulated on these CAR-T cells, indicating that these inhibitory molecules may result in dysfunction and poor persistence of CAR-T cells $(194,195)$.

Recently, CRISPR-Cas9 technology has been applied to knock out IR itself, and studies have been conducted on PD1 and LAG-3 in CD19-BB $\zeta$ CAR-T cells $(196,197)$. In mouse xenograft models, knockout of IR-derived CAR-T cells effectively eradicated tumors $(196,197)$. This method has also been applied to solid tumors. CRISPR-Cas9 was utilized to knock out PD1 in CD133-specific CAR-T cells. In a mouse glioma model, CD133-specific CAR-T cells with PD-1 knockout enhanced the control of tumor growth compared to control CD133-CAR-T cells (198). Based on the encouraging results obtained above, CAR-T cells edited by CRISPR-Cas9 have entered clinical trials. For example, CD19-specific CAR-T cells with PD-1 knockout are being investigated in PhaseIclinical trials (NCT03298828).

Additionally, CAR-T cells are designed to secrete immune checkpoint antibodies themselves. In $\mathrm{CD} 9^{+}$lung cancer xenograft models, CAR-T cells have been engineered to secrete anti-PD-1 antibodies and significantly improved antitumor activity, manifested by enhanced $\mathrm{T}$ cell proliferation, increased 
cytotoxicity, and prolonged overall survival (199). Compared with standard CAR-T cells, anti-CAIX CAR-T cells secreting anti-PD-L1 antibodies significantly increase antitumor activity, as evidenced by enhanced cytokine production and immune cell recruitment and the significant reduction in tumor size in the humanized ccRCC mouse model (200). Whether these CARs are likely to succeed in the body is still unknown. Currently, CAR$\mathrm{T}$ cells, which are designed to secrete PD-1, CTLA-4 or PDL1 antibodies, have entered clinical trials for cancers expressing MUC1, EGFR, EGFRVIII, and mesothelin (201).

In addition, other strategies have been used to enhance CAR$\mathrm{T}$ cell function in TME, including inhibition of inhibitory soluble molecules such as IDO, adenosine and VEGF, and protection from immunosuppression of non-tumor cells, such as MDSCs and TAMs. Interestingly, the combination of EGFRVIIICAR$\mathrm{T}$ cells with the blockade of IDO1 significantly reduces tumor growth in a xenograft colon cancer model (202). In HER2 CAR$\mathrm{T}$ cells, blockade of adenosine $2 \mathrm{~A}$ receptor enhances CAR- T cell activation and cytokine production, which contributes to the improved antitumor efficacy of CAR-T cells (203). The addition of PD-1 blockade further enhanced $\mathrm{T}$ cell immunity (203). Also, VEGF blockade has achieved success in solid tumors including melanoma, and VEGF-targeted CAR-T cells have achieved good results in a variety of preclinical solid tumor models $(187,204,205)$.

\section{CHALLENGES AND POSSIBLE SOLUTIONS}

Resistance to therapy is a major challenge in cancer immunotherapy. Defects involved in IFN $\gamma$ signaling and antigen presentation pathways, as tumor-intrinsic alterations, can lead to resistance to cancer immunotherapy, which explains why immunotherapy is not effective in some cancer patients $(206,207)$. In melanoma patients treated with PD-1 blockade, for example, the acquired resistance is attributed to the inactivation of IFN $\gamma$ signaling and defects in the antigen presentation mechanism (206).

Moreover, alterations in the functional state of TILs are also among the reasons for resistance to immunotherapy (208). Interestingly, after adoptive transfer of MART-1 TCR-transduced $\mathrm{T}$ cells in advanced melanoma patients, the $\mathrm{T}$ cell functional phenotype was altered during relapse, which was characterized by a complete loss of initial cytotoxic activity or an acquired inflammatory cytokine secretion but lack of cytotoxicity (209). Therefore, to assess whether changes in the dysfunctional state are also critical in mediating the immunotherapeutic resistance of cancer patients, it will be of value to compare monotherapy and combination therapy at the beginning of treatment and at the moment of resistance.

In addition, reactivation of treatment-induced tumor-specific $\mathrm{T}$ cells may unexpectedly promote the further progression of $\mathrm{T}$ cell dysfunction. By comparing longitudinal samples of colon cancer models in both immunocompetent and immunodeficient mice, we found two important tumor escape mechanisms involving the accumulation of immunosuppressive cell populations (e.g., Tregs) and enhanced expression of multiple inhibitory receptors on $\mathrm{T}$ cells, which contribute to the deterioration of T cell function (210). Given this, Chauvin et al. discovered that, after PD-1 blockade in vitro, TIGIT expression was increased on TA-specific CD8 ${ }^{+}$T cells (25). Dual TIGIT and PD-1 blockade could promote the effector function of $\mathrm{CD}^{+} \mathrm{T}$ cells. Similarly, Tim-3 was upregulated on TILs in a PI3K/AKTdependent manner upon PD-1 blockade. Notably, the combined blockade of the two receptors significantly improved antitumor immunity (211). In a mouse lung cancer model, several other immune checkpoints, such as CTLA-4, Tim-3, and LAG-3, were also found to be upregulated upon resistance to $\mathrm{PD}-1$ blockade (212). Therefore, upregulation of other immune checkpoints also provides a potential resistance mechanism after anti-PD1 treatment.

\section{CONCLUSIONS}

Dysfunctional $\mathrm{T}$ cells have various cellular states and different characteristics in cancer. Both persistent TCR triggering and T-cell internal and external factors can affect the fate of dysfunctional $\mathrm{T}$ cells. Although the characteristics of $\mathrm{T}$ cell dysfunction in cancer are similar to those of $\mathrm{T}$ cell dysfunction in chronic viral infection, there are various factors in the complicated TME that promote the process of immunosuppression, which can further shape $\mathrm{T}$ cell dysfunction in cancer. Gradually, it is conceivable that dysfunctional T cells in cancer differ from those found in chronic infection sites. However, heterogeneous dysfunctional $\mathrm{T}$ cell states still exist among different tumors and even within tumors. To reverse dysfunctional $\mathrm{T}$ cells and restore antitumor immunity, immune checkpoint blockade and related combination therapies have been applied. However, some challenges still remain to be solved, such as how to maintain long-lasting efficacy and how to choose the best combination therapy. Moreover, it is essential to understand the processes that drive and maintain these different dysfunctional $\mathrm{T}$ cell states. Continued advances in technology will help achieve this goal, supporting the development of personalized strategies for targeting dysfunctional $\mathrm{T}$ cells to achieve precise treatment for cancer patients.

\section{AUTHOR CONTRIBUTIONS}

AX conceived and wrote the manuscript and prepared the figures. YZ and JX contributed to performing the literature collection. TY and X-JL directed and approved the manuscript. All authors declare no conflict of interest and gave the final approval of the manuscript submission.

\section{FUNDING}

This work was supported by grants from the National Natural Science Foundation of China (Grant No. 81772596 to X-JL). 


\section{REFERENCES}

1. Kaech SM, Cui W. Transcriptional control of effector and memory $\mathrm{CD}^{+} \mathrm{T}$ cell differentiation. Nat Rev Immunol. (2012) 12:749-61. doi: $10.1038 /$ nri3307

2. Cui W, Kaech SM. Generation of effector $\mathrm{CD}^{+} \mathrm{T}$ cells and their conversion to memory $\mathrm{T}$ cells. Immunol Rev. (2010) 236:151-66. doi: 10.1111/j.1600-065X.2010.00926.x

3. Wherry EJ, Blattman JN, Murali-Krishna K, van der Most R, Ahmed R. Viral persistence alters CD8 T-cell immunodominance and tissue distribution and results in distinct stages of functional impairment. J Virol. (2003) 77:4911-27. doi: 10.1128/jvi.77.8.4911-4927.2003

4. Wherry EJ, Ha SJ, Kaech SM, Haining WN, Sarkar S, Kalia V, et al. Molecular signature of $\mathrm{CD}^{+} \mathrm{T}$ cell exhaustion during chronic viral infection. Immunity. (2007) 27:670-84. doi: 10.1016/j.immuni.2007.09.006

5. Baitsch L, Baumgaertner P, Devevre E, Raghav SK, Legat A, Barba L, et al. Exhaustion of tumor-specific CD8(+) T cells in metastases from melanoma patients. J Clin Invest. (2011) 121:2350-60. doi: 10.1172/JCI46102

6. Wherry EJ, Kurachi M. Molecular and cellular insights into T cell exhaustion. Nat Rev Immunol. (2015) 15:486-99. doi: 10.1038/nri3862

7. Schietinger A, Philip M, Krisnawan VE, Chiu EY, Delrow JJ, Basom $\mathrm{RS}$, et al. Tumor-specific $\mathrm{T}$ cell dysfunction is a dynamic antigen-driven differentiation program initiated early during tumorigenesis. Immunity. (2016) 45:389-401. doi: 10.1016/j.immuni.2016.07.011s

8. Bucks CM, Norton JA, Boesteanu AC, Mueller YM, Katsikis PD. Chronic antigen stimulation alone is sufficient to drive $\mathrm{CD}^{+} \mathrm{T}$ cell exhaustion. $J$ Immunol. (2009) 182:6697-708. doi: 10.4049/jimmunol.0800997

9. Blackburn SD, Shin H, Haining WN, Zou T, Workman CJ, Polley A, et al. Coregulation of $\mathrm{CD}^{+} \mathrm{T}$ cell exhaustion by multiple inhibitory receptors during chronic viral infection. Nat Immunol. (2009) 10:29-37. doi: $10.1038 /$ ni. 1679

10. Agnellini P, Wolint P, Rehr M, Cahenzli J, Karrer U, Oxenius A. Impaired NFAT nuclear translocation results in split exhaustion of virus-specific CD8 ${ }^{+}$ $\mathrm{T}$ cell functions during chronic viral infection. Proc Natl Acad Sci USA. (2007) 104:4565-70. doi: 10.1073/pnas.0610335104

11. Chiu YL, Shan L, Huang H, Haupt C, Bessell C, Canaday DH, et al. Sprouty-2 regulates HIV-specific T cell polyfunctionality. J Clin Invest. (2014) 124:198208. doi: 10.1172/JCI70510

12. Martinez GJ, Pereira RM, Aijo T, Kim EY, Marangoni F, Pipkin ME, et al. The transcription factor NFAT promotes exhaustion of activated CD8 $(+)$ T cells. Immunity. (2015) 42:265-78. doi: 10.1016/j.immuni.2015.01.006

13. Oestreich KJ, Yoon $\mathrm{H}$, Ahmed R, Boss JM. NFATc1 regulates PD1 expression upon $\mathrm{T}$ cell activation. J Immunol. (2008) 181:4832-9. doi: 10.4049/jimmunol.181.7.4832

14. Honda T, Egen JG, Lammermann T, Kastenmuller W, Torabi-Parizi P, Germain RN. Tuning of antigen sensitivity by $\mathrm{T}$ cell receptor-dependent negative feedback controls $\mathrm{T}$ cell effector function in inflamed tissues. Immunity. (2014) 40:235-47. doi: 10.1016/j.immuni.2013.11.017

15. Okazaki T, Chikuma S, Iwai Y, Fagarasan S, Honjo T. A rheostat for immune responses: the unique properties of PD-1 and their advantages for clinical application. Nat Immunol. (2013) 14:1212-8. doi: 10.1038/ni.2762

16. Wherry EJ. $\mathrm{T}$ cell exhaustion. Nat Immunol. (2011) 12:492-9. doi: $10.1038 /$ ni.2035

17. Akbar AN, Henson SM. Are senescence and exhaustion intertwined or unrelated processes that compromise immunity? Nat Rev Immunol. (2011) 11:289-95. doi: 10.1038/nri2959

18. Schietinger A, Greenberg PD. Tolerance and exhaustion: defining mechanisms of $\mathrm{T}$ cell dysfunction. Trends Immunol. (2014) 35:51-60. doi: 10.1016/j.it.2013.10.001

19. Zajac AJ, Blattman JN, Murali-Krishna K, Sourdive DJ, Suresh M, Altman JD, et al. Viral immune evasion due to persistence of activated T cells without effector function. J Exp Med. (1998) 188:2205-13.

20. Ahmadzadeh M, Johnson LA, Heemskerk B, Wunderlich JR, Dudley ME, White DE, et al. Tumor antigen-specific CD8 T cells infiltrating the tumor express high levels of PD-1 and are functionally impaired. Blood. (2009) 114:1537-44. doi: 10.1182/blood-2008-12-195792
21. Fourcade J, Kudela P, Sun Z, Shen H, Land SR, Lenzner D, et al. PD-1 is a regulator of NY-ESO-1-specific CD8 ${ }^{+} \mathrm{T}$ cell expansion in melanoma patients. J Immunol. (2009) 182:5240-9. doi: 10.4049/jimmunol.0803245

22. Day CL, Kaufmann DE, Kiepiela P, Brown JA, Moodley ES, Reddy S, et al. PD-1 expression on HIV-specific T cells is associated with T-cell exhaustion and disease progression. Nature. (2006) 443:350-4. doi: 10.1038/nature05115

23. Woo SR, Turnis ME, Goldberg MV, Bankoti J, Selby M, Nirschl CJ, et al. Immune inhibitory molecules LAG-3 and PD-1 synergistically regulate Tcell function to promote tumoral immune escape. Cancer Res. (2012) 72:91727. doi: 10.1158/0008-5472.CAN-11-1620

24. Johnston RJ, Comps-Agrar L, Hackney J, Yu X, Huseni M, Yang Y, et al. The immunoreceptor TIGIT regulates antitumor and antiviral CD8(+) $\mathrm{T}$ cell effector function. Cancer Cell. (2014) 26:923-37. doi: 10.1016/j.ccell.2014.10.018

25. Chauvin JM, Pagliano O, Fourcade J, Sun Z, Wang H, Sander C, et al. TIGIT and PD-1 impair tumor antigen-specific CD8(+) T cells in melanoma patients. J Clinl Invest. (2015) 125:2046-58. doi: 10.1172/JCI80445

26. Fourcade J, Sun Z, Benallaoua M, Guillaume P, Luescher IF, Sander C, et al. Upregulation of Tim-3 and PD-1 expression is associated with tumor antigen-specific CD8 ${ }^{+} \mathrm{T}$ cell dysfunction in melanoma patients. J Exp Med. (2010) 207:2175-86. doi: 10.1084/jem.20100637

27. Fourcade J, Sun Z, Pagliano O, Guillaume P, Luescher IF, Sander C, et al. CD8 $(+) \mathrm{T}$ cells specific for tumor antigens can be rendered dysfunctional by the tumor microenvironment through upregulation of the inhibitory receptors BTLA and PD-1. Cancer Res. (2012) 72:887-96. doi: 10.1158/0008-5472.CAN-11-2637

28. Sharma P, Allison JP. The future of immune checkpoint therapy. Science. (2015) 348:56-61. doi: 10.1126/science.aaa8172

29. Marin-Acevedo JA, Dholaria B, Soyano AE, Knutson KL, Chumsri S, Lou Y. Next generation of immune checkpoint therapy in cancer: new developments and challenges. J Hematol Oncol. (2018) 11:39. doi: 10.1186/s13045-018-0582-8

30. Robert C, Ribas A, Wolchok JD, Hodi FS, Hamid O, Kefford R, et al. Anti-programmed-death-receptor-1 treatment with pembrolizumab in ipilimumab-refractory advanced melanoma: a randomised dosecomparison cohort of a phase 1 trial. Lancet. (2014) 384:1109-17. doi: 10.1016/S0140-6736(14)60958-2

31. Motzer RJ, Escudier B, McDermott DF, George S, Hammers HJ, Srinivas S, et al. Nivolumab versus everolimus in advanced renal-cell carcinoma. $N$ Engl J Med. (2015) 373:1803-13. doi: 10.1056/NEJMoa1510665

32. Fehrenbacher L, Spira A, Ballinger M, Kowanetz M, Vansteenkiste J, Mazieres J, et al. Atezolizumab versus docetaxel for patients with previously treated non-small-cell lung cancer (POPLAR): a multicentre, openlabel, phase 2 randomised controlled trial. Lancet. (2016) 387:1837-46. doi: 10.1016/S0140-6736(16)00587-0

33. Li X, Cheng Y, Zhang M, Yan J, Li L, Fu X, et al. Activity of pembrolizumab in relapsed/refractory NK/T-cell lymphoma. J Hematol Oncol. (2018) 11:15. doi: 10.1186/s13045-018-0559-7

34. Araki K, Youngblood B, Ahmed R. Programmed cell death 1-directed immunotherapy for enhancing T-cell function. Cold Spring Harb Symp Quant Biol. (2013) 78:239-47. doi: 10.1101/sqb.2013.78.019869

35. Duraiswamy J, Ibegbu CC, Masopust D, Miller JD, Araki K, Doho GH, et al. Phenotype, function, and gene expression profiles of programmed death1(hi) CD8 T cells in healthy human adults. J Immunol. (2011) 186:4200-12. doi: 10.4049/jimmunol.1001783

36. Sharpe AH, Wherry EJ, Ahmed R, Freeman GJ. The function of programmed cell death 1 and its ligands in regulating autoimmunity and infection. Nat Immunol. (2007) 8:239-45. doi: 10.1038/ni1443

37. Taube JM, Anders RA, Young GD, Xu H, Sharma R, McMiller TL, et al. Colocalization of inflammatory response with B7-h1 expression in human melanocytic lesions supports an adaptive resistance mechanism of immune escape. Sci Trans Med. (2012) 4:127ra37. doi: 10.1126/scitranslmed.30 03689

38. Huang YH, Zhu C, Kondo Y, Anderson AC, Gandhi A, Russell A, et al. CEACAM1 regulates TIM-3-mediated tolerance and exhaustion. Nature. (2015) 517:386-90. doi: 10.1038/nature13848 
39. Zhu C, Anderson AC, Schubart A, Xiong H, Imitola J, Khoury SJ, et al. The Tim-3 ligand galectin-9 negatively regulates T helper type 1 immunity. Nat Immunol. (2005) 6:1245-52. doi: 10.1038/ni1271

40. Chiba S, Baghdadi M, Akiba H, Yoshiyama H, Kinoshita I, Dosaka-Akita H, et al. Tumor-infiltrating DCs suppress nucleic acid-mediated innate immune responses through interactions between the receptor TIM-3 and the alarmin HMGB1. Nat Immunol. (2012) 13:832-42. doi: 10.1038/ni.2376

41. Freeman GJ, Casasnovas JM, Umetsu DT, DeKruyff RH. TIM genes: a family of cell surface phosphatidylserine receptors that regulate innate and adaptive immunity. Immunol Rev. (2010) 235:172-89. doi: 10.1111/j.0105-2896.2010.00903.x

42. Linsley PS, Greene JL, Brady W, Bajorath J, Ledbetter JA, Peach R. Human B7-1 (CD80) and B7-2 (CD86) bind with similar avidities but distinct kinetics to CD28 and CTLA-4 receptors. Immunity. (1994) 1:793-801.

43. Bottino C, Castriconi R, Pende D, Rivera P, Nanni M, Carnemolla B, et al. Identification of PVR (CD155) and Nectin-2 (CD112) as cell surface ligands for the human DNAM-1 (CD226) activating molecule. J Exp Med. (2003) 198:557-67. doi: 10.1084/jem.20030788

44. Yu X, Harden K, Gonzalez LC, Francesco M, Chiang E, Irving B, et al. The surface protein TIGIT suppresses $\mathrm{T}$ cell activation by promoting the generation of mature immunoregulatory dendritic cells. Nat Immunol. (2009) 10:48-57. doi: 10.1038/ni.1674

45. Egen JG, Allison JP. Cytotoxic T lymphocyte antigen-4 accumulation in the immunological synapse is regulated by TCR signal strength. Immunity. (2002) 16:23-35. doi: 10.1016/S1074-7613(01)00259-X

46. Joller N, Hafler JP, Brynedal B, Kassam N, Spoerl S, Levin SD, et al. Cutting edge: TIGIT has T cell-intrinsic inhibitory functions. J Immunol. (2011) 186:1338-42. doi: 10.4049/jimmunol.1003081

47. Yokosuka T, Takamatsu M, Kobayashi-Imanishi W, Hashimoto-Tane A, Azuma M, Saito T. Programmed cell death 1 forms negative costimulatory microclusters that directly inhibit $\mathrm{T}$ cell receptor signaling by recruiting phosphatase SHP2. J Exp Med. (2012) 209:1201-17. doi: $10.1084 /$ jem.20112741

48. Hui E, Cheung J, Zhu J, Su X, Taylor MJ, Wallweber HA, et al. T cell costimulatory receptor CD28 is a primary target for PD-1-mediated inhibition. Science. (2017) 355:1428-33. doi: 10.1126/science.aaf1292

49. Kamphorst AO, Wieland A, Nasti T, Yang S, Zhang R, Barber DL, et al. Rescue of exhausted CD8 T cells by PD-1-targeted therapies is CD28dependent. Science. (2017) 355:1423-7. doi: 10.1126/science.aaf0683

50. Curran MA, Montalvo W, Yagita H, Allison JP. PD-1 and CTLA-4 combination blockade expands infiltrating $\mathrm{T}$ cells and reduces regulatory $\mathrm{T}$ and myeloid cells within B16 melanoma tumors. Proc Natl Acad Sci USA. (2010) 107:4275-80. doi: 10.1073/pnas.0915174107

51. Liu F, Liu Y, Chen Z. Tim-3 expression and its role in hepatocellular carcinoma. J Hematol Oncol. (2018) 11:126. doi: 10.1186/s13045-018-0667-4

52. Nishikawa H, Sakaguchi S. Regulatory $\mathrm{T}$ cells in cancer immunotherapy. Curr Opin Immunol. (2014) 27:1-7. doi: 10.1016/j.coi.2013.12.005

53. Sharabi A, Tsokos MG, Ding Y, Malek TR, Klatzmann D, Tsokos GC. Regulatory T cells in the treatment of disease. Nat Rev Drug Dis. (2018) 17:823-44. doi: 10.1038/nrd.2018.148

54. Tanaka A, Sakaguchi S. Regulatory $\mathrm{T}$ cells in cancer immunotherapy. Cell Res. (2017) 27:109-18. doi: 10.1038/cr.2016.151

55. Francisco LM, Sage PT, Sharpe AH. The PD-1 pathway in tolerance and autoimmunity. Immunol Rev. (2010) 236:219-42. doi: 10.1111/j.1600-065X.2010.00923.x

56. Joller N, Lozano E, Burkett PR, Patel B, Xiao S, Zhu C, et al. Treg cells expressing the coinhibitory molecule TIGIT selectively inhibit proinflammatory Th1 and Th17 cell responses. Immunity. (2014) 40:569-81. doi: 10.1016/j.immuni.2014.02.012

57. Kurtulus S, Sakuishi K, Ngiow SF, Joller N, Tan DJ, Teng MW, et al. TIGIT predominantly regulates the immune response via regulatory $\mathrm{T}$ cells. J Clin Invest. (2015) 125:4053-62. doi: 10.1172/JCI81187

58. Turk MJ, Guevara-Patino JA, Rizzuto GA, Engelhorn ME, Sakaguchi S, Houghton AN. Concomitant tumor immunity to a poorly immunogenic melanoma is prevented by regulatory T cells. J Exp Med. (2004) 200:771-82. doi: 10.1084/jem.20041130

59. Sugiyama D, Nishikawa H, Maeda Y, Nishioka M, Tanemura A, Katayama $\mathrm{I}$, et al. Anti-CCR4 mAb selectively depletes effector-type FoxP3+CD4+ regulatory $\mathrm{T}$ cells, evoking antitumor immune responses in humans. Proc Natl Acad Sci USA. (2013) 110:17945-50. doi: 10.1073/pnas.1316796110s

60. Bulliard Y, Jolicoeur R, Zhang J, Dranoff G, Wilson NS, Brogdon JL. OX40 engagement depletes intratumoral Tregs via activating FcgammaRs, leading to antitumor efficacy. Immunol Cell Biol. (2014) 92:475-80. doi: $10.1038 /$ icb.2014.26

61. Quezada SA, Peggs KS, Simpson TR, Shen Y, Littman DR, Allison JP. Limited tumor infiltration by activated $\mathrm{T}$ effector cells restricts the therapeutic activity of regulatory $\mathrm{T}$ cell depletion against established melanoma. J Exp Med. (2008) 205:2125-38. doi: 10.1084/jem.20080099

62. Simpson TR, Li F, Montalvo-Ortiz W, Sepulveda MA, Bergerhoff K, Arce $\mathrm{F}$, et al. Fc-dependent depletion of tumor-infiltrating regulatory $\mathrm{T}$ cells codefines the efficacy of anti-CTLA-4 therapy against melanoma. J Exp Med. (2013) 210:1695-710. doi: 10.1084/jem.20130579

63. Bulliard Y, Jolicoeur R, Windman M, Rue SM, Ettenberg S, Knee DA, et al. Activating $\mathrm{Fc}$ gamma receptors contribute to the antitumor activities of immunoregulatory receptor-targeting antibodies. J Exp Med. (2013) 210:1685-93. doi: 10.1084/jem.20130573

64. Zhao Q, Kuang DM, Wu Y, Xiao X, Li XF, Li TJ, et al. Activated CD69+ $\mathrm{T}$ cells foster immune privilege by regulating IDO expression in tumor-associated macrophages. J Immunol. (2012) 188:1117-24. doi: 10.4049/jimmunol.1100164

65. Ye XZ, Xu SL, Xin YH, Yu SC, Ping YF, Chen L, et al. Tumorassociated microglia/macrophages enhance the invasion of glioma stemlike cells via TGF-betal signaling pathway. J Immunol. (2012) 189:444-53. doi: 10.4049/jimmunol.1103248

66. Colegio OR, Chu NQ, Szabo AL, Chu T, Rhebergen AM, Jairam V, et al. Functional polarization of tumour-associated macrophages by tumourderived lactic acid. Nature. (2014) 513:559-63. doi: 10.1038/nature13490

67. Budhwar S, Verma P, Verma R, Rai S, Singh K. The Yin and Yang of myeloid derived suppressor cells. Front Immunol. (2018) 9:2776. doi: 10.3389/fimmu.2018.02776

68. Veglia F, Perego M, Gabrilovich D. Myeloid-derived suppressor cells coming of age. Nat Immunol. (2018) 19:108-19. doi: 10.1038/s41590-017-0022-x

69. Gabrilovich DI, Nagaraj S. Myeloid-derived suppressor cells as regulators of the immune system. Nat Rev Immunol. (2009) 9:162-74. doi: $10.1038 /$ nri2506

70. Kalluri R. The biology and function of fibroblasts in cancer. Nat Rev Cancer. (2016) 16:582-98. doi: 10.1038/nrc.2016.73

71. Chen X, Song E. Turning foes to friends: targeting cancerassociated fibroblasts. Nat Rev Drug Discov. (2018) 18:99-115. doi: 10.1038/s41573-018-0004-1

72. Ko SY, Barengo N, Ladanyi A, Lee JS, Marini F, Lengyel E, et al. HOXA9 promotes ovarian cancer growth by stimulating cancer-associated fibroblasts. J Clin Invest. (2012) 122:3603-17. doi: 10.1172/JCI62229

73. Lakins MA, Ghorani E, Munir H, Martins CP, Shields JD. Cancer-associated fibroblasts induce antigen-specific deletion of CD8(+) T Cells to protect tumour cells. Nat Commun. (2018) 9:948. doi: 10.1038/s41467-018-03347-0

74. Dirat B, Bochet L, Dabek M, Daviaud D, Dauvillier S, Majed B, et al. Cancer-associated adipocytes exhibit an activated phenotype and contribute to breast cancer invasion. Cancer Res. (2011) 71:2455-65. doi: 10.1158/0008-5472.CAN-10-3323

75. Nieman KM, Kenny HA, Penicka CV, Ladanyi A, Buell-Gutbrod R, Zillhardt $\mathrm{MR}$, et al. Adipocytes promote ovarian cancer metastasis and provide energy for rapid tumor growth. Nat Med. (2011) 17:1498-503. doi: 10.1038/nm.2492

76. Huang CK, Chang PH, Kuo WH, Chen CL, Jeng YM, Chang KJ, et al. Adipocytes promote malignant growth of breast tumours with monocarboxylate transporter 2 expression via beta-hydroxybutyrate. Nat Commun. (2017) 8:14706. doi: 10.1038/ncomms14706

77. Piali L, Fichtel A, Terpe HJ, Imhof BA, Gisler RH. Endothelial vascular cell adhesion molecule 1 expression is suppressed by melanoma and carcinoma. J Exp Med. (1995) 181:811-6. doi: 10.1084/jem.181.2.811

78. Mulligan JK, Rosenzweig SA, Young MR. Tumor secretion of VEGF induces endothelial cells to suppress $\mathrm{T}$ cell functions through the production of PGE2. J Immunother. (2010) 33:126-35. doi: 10.1097/CJI.0b013e3181b91c9c

79. Motz GT, Santoro SP, Wang LP, Garrabrant T, Lastra RR, Hagemann IS, et al. Tumor endothelium FasL establishes a selective immune barrier promoting tolerance in tumors. Nat Med. (2014) 20:607-15. doi: 10.1038/nm.3541 
80. Ghesquiere B, Wong BW, Kuchnio A, Carmeliet P. Metabolism of stromal and immune cells in health and disease. Nature. (2014) 511:167-76. doi: $10.1038 /$ nature 13312

81. Card CM, Yu SS, Swartz MA. Emerging roles of lymphatic endothelium in regulating adaptive immunity. J Clin Invest. (2014) 124:943-52. doi: 10.1172/JCI73316

82. Humbert M, Hugues S, Dubrot J. Shaping of peripheral $\mathrm{T}$ cell responses by lymphatic endothelial cells. Front Immunol. (2016) 7:684. doi: 10.3389/fimmu.2016.00684

83. Mannino MH, Zhu Z, Xiao H, Bai Q, Wakefield MR, Fang Y. The paradoxical role of IL-10 in immunity and cancer. Cancer Lett. (2015) 367:103-7. doi: 10.1016/j.canlet.2015.07.009

84. Moore KW, de Waal Malefyt R, Coffman RL, O’Garra A. Interleukin-10 and the interleukin-10 receptor. Ann Rev Immunol. (2001) 19:683-765. doi: 10.1146/annurev.immunol.19.1.683

85. Pestka S, Krause CD, Sarkar D, Walter MR, Shi Y, Fisher PB. Interleukin-10 and related cytokines and receptors. Ann Rev Immunol. (2004) 22:929-79. doi: 10.1146/annurev.immunol.22.012703.104622

86. Drennan S, D’Avola A, Gao Y, Weigel C, Chrysostomou E, Steele AJ, et al. IL10 production by CLL cells is enhanced in the anergic IGHV mutated subset and associates with reduced DNA methylation of the IL10 locus. Leukemia. (2017) 31:1686-94. doi: 10.1038/leu.2016.356

87. Meng X, Grotsch B, Luo Y, Knaup KX, Wiesener MS, Chen XX, et al. Hypoxia-inducible factor-1alpha is a critical transcription factor for IL10-producing B cells in autoimmune disease. Nat Commun. (2018) 9:251. doi: 10.1038/s41467-017-02683-x

88. Fujii S, Shimizu K, Shimizu T, Lotze MT. Interleukin-10 promotes the maintenance of antitumor CD8(+) T-cell effector function in situ. Blood. (2001) 98:2143-51. doi: 10.1182/blood.v98.7.2143

89. Sharma S, Stolina M, Lin Y, Gardner B, Miller PW, Kronenberg M, et al. T cell-derived IL-10 promotes lung cancer growth by suppressing both T cell and APC function. J Immunol. (1999) 163:5020-8.

90. Lamichhane P, Karyampudi L, Shreeder B, Krempski J, Bahr D, Daum J, et al. IL10 release upon PD-1 blockade sustains immunosuppression in ovarian cancer. Cancer Res. (2017) 77:6667-78. doi: 10.1158/0008-5472.CAN-17-0740

91. Mumm JB, Emmerich J, Zhang X, Chan I, Wu L, Mauze S, et al. IL10 elicits IFNgamma-dependent tumor immune surveillance. Cancer Cell. (2011) 20:781-96. doi: 10.1016/j.ccr.2011.11.003

92. McNab F, Mayer-Barber K, Sher A, Wack A, O'Garra A. Type I interferons in infectious disease. Nat Rev Immunol. (2015) 15:87-103. doi: 10.1038/nri3787

93. Curtsinger JM, Mescher MF. Inflammatory cytokines as a third signal for $\mathrm{T}$ cell activation. Curr Opin Immunol. (2010) 22:333-40. doi: 10.1016/j.coi.2010.02.013

94. Teijaro JR, Ng C, Lee AM, Sullivan BM, Sheehan KC, Welch M, et al. Persistent LCMV infection is controlled by blockade of type I interferon signaling. Science. (2013) 340:207-11. doi: 10.1126/science.12 35214

95. Terawaki S, Chikuma S, Shibayama S, Hayashi T, Yoshida T, Okazaki T, et al. IFN-alpha directly promotes programmed cell death-1 transcription and limits the duration of T cell-mediated immunity. J Immunol. (2011) 186:2772-9. doi: 10.4049/jimmunol.1003208

96. Uyttenhove C, Pilotte L, Theate I, Stroobant V, Colau D, Parmentier N, et al. Evidence for a tumoral immune resistance mechanism based on tryptophan degradation by indoleamine 2,3-dioxygenase. Nat Med. (2003) 9:1269-74. doi: $10.1038 / \mathrm{nm} 934$

97. Sharma MD, Baban B, Chandler P, Hou DY, Singh N, Yagita H, et al. Plasmacytoid dendritic cells from mouse tumor-draining lymph nodes directly activate mature Tregs via indoleamine 2,3-dioxygenase. J Clin Invest. (2007) 117:2570-82. doi: 10.1172/JCI31911

98. Spranger S, Spaapen RM, Zha Y, Williams J, Meng Y, Ha TT, et al. Up-regulation of PD-L1, IDO, and T(regs) in the melanoma tumor microenvironment is driven by CD8(+) T cells. Sci Trans Med. (2013) 5:200ra116. doi: 10.1126/scitranslmed.3006504

99. Munn DH, Mellor AL. IDO in the tumor microenvironment: inflammation, counter-regulation, and tolerance. Trends Immunol. (2016) 37:193-207. doi: 10.1016/j.it.2016.01.002
100. Munn DH, Mellor AL. Indoleamine 2,3-dioxygenase and tumorinduced tolerance. J Clin Invest. (2007) 117:1147-54. doi: 10.1172/JCI 31178

101. Holmgaard RB, Zamarin D, Munn DH, Wolchok JD, Allison JP. Indoleamine 2,3-dioxygenase is a critical resistance mechanism in antitumor $\mathrm{T}$ cell immunotherapy targeting CTLA-4. J Exp Med. (2013) 210:1389-402. doi: 10.1084/jem.20130066

102. Raskovalova T, Lokshin A, Huang X, Su Y, Mandic M, Zarour HM, et al. Inhibition of cytokine production and cytotoxic activity of human antimelanoma specific $\mathrm{CD}^{+}$and $\mathrm{CD} 4+\mathrm{T}$ lymphocytes by adenosineprotein kinase A type I signaling. Cancer Res. (2007) 67:5949-56. doi: 10.1158/0008-5472.CAN-06-4249S

103. Ohta A, Sitkovsky M. Extracellular adenosine-mediated modulation of regulatory $\mathrm{T}$ cells. Front Immunol. (2014) 5:304. doi: 10.3389/fimmu.2014.00304

104. Terme M, Pernot S, Marcheteau E, Sandoval F, Benhamouda N, Colussi O, et al. VEGFA-VEGFR pathway blockade inhibits tumor-induced regulatory T-cell proliferation in colorectal cancer. Cancer Res. (2013) 73:539-49. doi: 10.1158/0008-5472.CAN-12-2325

105. Gabrilovich DI, Chen HL, Girgis KR, Cunningham HT, Meny GM, Nadaf $\mathrm{S}$, et al. Production of vascular endothelial growth factor by human tumors inhibits the functional maturation of dendritic cells. Nat Med. (1996) 2:1096103.

106. Voron T, Colussi O, Marcheteau E, Pernot S, Nizard M, Pointet AL, et al. VEGF-A modulates expression of inhibitory checkpoints on $\mathrm{CD}^{+} \mathrm{T}$ cells in tumors. J Exp Med. (2015) 212:139-48. doi: 10.1084/jem.20140559

107. Tauriello DVF, Palomo-Ponce S, Stork D, Berenguer-Llergo A, BadiaRamentol J, Iglesias $M$, et al. TGFbeta drives immune evasion in genetically reconstituted colon cancer metastasis. Nature. (2018) 554:538-43. doi: $10.1038 /$ nature25492.S

108. Mariathasan S, Turley SJ, Nickles D, Castiglioni A, Yuen K, Wang Y, et al. TGFbeta attenuates tumour response to PD-L1 blockade by contributing to exclusion of T cells. Nature. (2018) 554:544-8. doi: 10.1038/nature25501

109. Collison LW, Workman CJ, Kuo TT, Boyd K, Wang Y, Vignali KM, et al. The inhibitory cytokine IL-35 contributes to regulatory T-cell function. Nature. (2007) 450:566-9. doi: 10.1038/nature06306

110. Wang RX, Yu CR, Dambuza IM, Mahdi RM, Dolinska MB, Sergeev YV, et al. Interleukin-35 induces regulatory B cells that suppress autoimmune disease. Nat Med. (2014) 20:633-41. doi: 10.1038/nm.3554

111. Shen P, Roch T, Lampropoulou V, O'Connor RA, Stervbo U, Hilgenberg $\mathrm{E}$, et al. IL-35-producing $\mathrm{B}$ cells are critical regulators of immunity during autoimmune and infectious diseases. Nature. (2014) 507:366-70. doi: $10.1038 /$ nature 12979

112. Sawant DV, Yano H, Chikina M, Zhang Q, Liao M, Liu C, et al. Adaptive plasticity of IL-10(+) and IL-35(+) Treg cells cooperatively promotes tumor T cell exhaustion. Nat Immunol. (2019) 20:724-35. doi: 10.1038/s41590-019-0346-9

113. Turnis ME, Sawant DV, Szymczak-Workman AL, Andrews LP, Delgoffe GM, Yano $\mathrm{H}$, et al. Interleukin-35 limits anti-tumor immunity. Immunity. (2016) 44:316-29. doi: 10.1016/j.immuni.2016.01.013

114. MacIver NJ, Michalek RD, Rathmell JC. Metabolic regulation of T lymphocytes. Annl Rev Immunol. (2013) 31:259-83. doi: 10.1146/annurev-immunol-032712-095956

115. Chang CH, Qiu J, O’Sullivan D, Buck MD, Noguchi T, Curtis JD, et al. Metabolic competition in the tumor microenvironment is a driver of cancer progression. Cell. (2015) 162:1229-41. doi: 10.1016/j.cell.2015.08.016

116. Ho PC, Bihuniak JD, Macintyre AN, Staron M, Liu X, Amezquita R, et al. phosphoenolpyruvate is a metabolic checkpoint of anti-tumor $\mathrm{T}$ cell responses. Cell. (2015) 162:1217-28. doi: 10.1016/j.cell.2015.08.012

117. Zhao E, Maj T, Kryczek I, Li W, Wu K, Zhao L, et al. Cancer mediates effector $\mathrm{T}$ cell dysfunction by targeting microRNAs and EZH2 via glycolysis restriction. Nat Immunol. (2016) 17:95-103. doi: 10.1038/ni.3313

118. Frauwirth KA, Riley JL, Harris MH, Parry RV, Rathmell JC, Plas DR, et al. The CD28 signaling pathway regulates glucose metabolism. Immunity. (2002) 16:769-77. doi: 10.1016/S1074-7613(02)00323-0

119. Patsoukis N, Bardhan K, Chatterjee P, Sari D, Liu B, Bell LN, et al. PD-1 alters T-cell metabolic reprogramming by inhibiting glycolysis and 
promoting lipolysis and fatty acid oxidation. Nat Commun. (2015) 6:6692. doi: $10.1038 /$ ncomms 7692

120. Lind DS. Arginine and cancer. J Nutr. (2004) 134:2837S-41S. doi: $10.1093 / \mathrm{jn} / 134.10 .2837 \mathrm{~S}$

121. Rodriguez PC, Ernstoff MS, Hernandez C, Atkins M, Zabaleta J, Sierra R, et al. Arginase I-producing myeloid-derived suppressor cells in renal cell carcinoma are a subpopulation of activated granulocytes. Cancer Res. (2009) 69:1553-60. doi: 10.1158/0008-5472.CAN-08-1921

122. Choi YS, Eto D, Yang JA, Lao C, Crotty S. Cutting edge: STAT1 is required for IL-6-mediated Bcl6 induction for early follicular helper cell differentiation. $J$ Immunol. (2013) 190:3049-53. doi: 10.4049/jimmunol.1203032

123. Munder M, Choi BS, Rogers M, Kropf P. L-arginine deprivation impairs Leishmania major-specific T-cell responses. Eur J Immunol. (2009) 39:216172. doi: 10.1002/eji.200839041

124. Carr EL, Kelman A, Wu GS, Gopaul R, Senkevitch E, Aghvanyan A, et al. Glutamine uptake and metabolism are coordinately regulated by ERK/MAPK during T lymphocyte activation. J Immunol. (2010) 185:103744. doi: 10.4049/jimmunol.0903586

125. Altman BJ, Stine ZE, Dang CV. From Krebs to clinic: glutamine metabolism to cancer therapy. Nat Rev Cancer. (2016) 16:749. doi: 10.1038/nrc.2016.114

126. Tanaka K, Sasayama T, Irino Y, Takata K, Nagashima H, Satoh N, et al. Compensatory glutamine metabolism promotes glioblastoma resistance to mTOR inhibitor treatment. J Clin Invest. (2015) 125:1591-602. doi: 10.1172/JCI78239

127. Platten M, Wick W, Van den Eynde BJ. Tryptophan catabolism in cancer: beyond IDO and tryptophan depletion. Cancer Res. (2012) 72:5435-40. doi: 10.1158/0008-5472.CAN-12-0569

128. Julliard W, Fechner JH, Mezrich JD. The aryl hydrocarbon receptor meets immunology: friend or foe? A little of both. Front Immunol. (2014) 5:458. doi: 10.3389/fimmu.2014.00458

129. Xia H, Wang W, Crespo J, Kryczek I, Li W, Wei S, et al. Suppression of FIP200 and autophagy by tumor-derived lactate promotes naive $\mathrm{T}$ cell apoptosis and affects tumor immunity. Sci Immunol. (2017) 2:eaan4631. doi: 10.1126/sciimmunol.aan4631

130. Choi SY, Collins CC, Gout PW, Wang Y. Cancer-generated lactic acid: a regulatory, immunosuppressive metabolite? J Pathol. (2013) 230:350-5. doi: $10.1002 /$ path. 4218

131. Pilon-Thomas S, Kodumudi KN, El-Kenawi AE, Russell S, Weber AM, Luddy $K$, et al. Neutralization of tumor acidity improves antitumor responses to immunotherapy. Cancer Res. (2016) 76:1381-90. doi: 10.1158/0008-5472.CAN-15-1743

132. Doedens AL, Phan AT, Stradner MH, Fujimoto JK, Nguyen JV, Yang E, et al. Hypoxia-inducible factors enhance the effector responses of CD8(+) T cells to persistent antigen. Nat Immunol. (2013) 14:1173-82. doi: 10.1038/ni.2714

133. Gropper Y, Feferman T, Shalit T, Salame TM, Porat Z, Shakhar G. Culturing CTLs under hypoxic conditions enhances their cytolysis and improves their anti-tumor function. Cell Rep. (2017) 20:2547-55. doi: 10.1016/j.celrep.2017.08.071

134. Fischer K, Hoffmann P, Voelkl S, Meidenbauer N, Ammer J, Edinger M, et al. Inhibitory effect of tumor cell-derived lactic acid on human T cells. Blood. (2007) 109:3812-9. doi: 10.1182/blood-2006-07-035972

135. Youngblood B, Oestreich KJ, Ha SJ, Duraiswamy J, Akondy RS, West EE, et al. Chronic virus infection enforces demethylation of the locus that encodes PD-1 in antigen-specific CD8(+) T cells. Immunity. (2011) 35:40012. doi: 10.1016/j.immuni.2011.06.015

136. Youngblood B, Noto A, Porichis F, Akondy RS, Ndhlovu ZM, Austin JW, et al. Cutting edge: prolonged exposure to HIV reinforces a poised epigenetic program for PD-1 expression in virus-specific CD8 T cells. J Immunol. (2013) 191:540-4. doi: 10.4049/jimmunol.1203161

137. Ahn E, Youngblood B, Lee J, Lee J, Sarkar S, Ahmed R. Demethylation of the PD-1 promoter is imprinted during the effector phase of CD8 T cell exhaustion. J Virol. (2016) 90:8934-46. doi: 10.1128/JVI.00798-16S

138. Simon S, Vignard V, Florenceau L, Dreno B, Khammari A, Lang F, et al. PD1 expression conditions $\mathrm{T}$ cell avidity within an antigen-specific repertoire. Oncoimmunology. (2016) 5:e1104448. doi: 10.1080/2162402X.2015.1104448

139. Ghoneim HE, Fan Y, Moustaki A, Abdelsamed HA, Dash P, Dogra P, et al. De Novo epigenetic programs inhibit PD-1 blockade-mediated T cell rejuvenation. Cell. (2017) 170:142-57. doi: 10.1016/j.cell.2017.06.007
140. Sen DR, Kaminski J, Barnitz RA, Kurachi M, Gerdemann U, Yates KB, et al. The epigenetic landscape of T cell exhaustion. Science. (2016) 354:1165-9. doi: 10.1126/science.aae0491

141. Pauken KE, Sammons MA, Odorizzi PM, Manne S, Godec J, Khan O, et al. Epigenetic stability of exhausted $\mathrm{T}$ cells limits durability of reinvigoration by PD-1 blockade. Science. (2016) 354:1160-5. doi: 10.1126/science.aaf2807

142. Mognol GP, Spreafico R, Wong V, Scott-Browne JP, Togher S, Hoffmann $\mathrm{A}$, et al. Exhaustion-associated regulatory regions in $\mathrm{CD} 8(+)$ tumorinfiltrating T cells. Proc Natl Acad Sci USA. (2017) 114:E2776-85. doi: 10.1073/pnas.1620498114

143. Philip M, Fairchild L, Sun L, Horste EL, Camara S, Shakiba M, et al. Chromatin states define tumour-specific $\mathrm{T}$ cell dysfunction and reprogramming. Nature. (2017) 545:452-6. doi: 10.1038/nature22367

144. Paley MA, Kroy DC, Odorizzi PM, Johnnidis JB, Dolfi DV, Barnett $\mathrm{BE}$, et al. Progenitor and terminal subsets of $\mathrm{CD}^{+} \mathrm{T}$ cells cooperate to contain chronic viral infection. Science. (2012) 338:1220-5. doi: 10.1126/science. 1229620

145. Doering TA, Crawford A, Angelosanto JM, Paley MA, Ziegler CG, Wherry EJ. Network analysis reveals centrally connected genes and pathways involved in $\mathrm{CD}^{+} \mathrm{T}$ cell exhaustion versus memory. Immunity. (2012) 37:1130-44. doi: 10.1016/j.immuni.2012.08.021

146. Intlekofer AM, Takemoto N, Wherry EJ, Longworth SA, Northrup JT, Palanivel VR, et al. Effector and memory $\mathrm{CD}^{+}{ }^{+} \mathrm{T}$ cell fate coupled by T-bet and eomesodermin. Nat Immunol. (2005) 6:1236-44. doi: 10.1038/ni1268

147. Pritchard GH, Kedl RM, Hunter CA. The evolving role of T-bet in resistance to infection. Nat Rev Immunol. (2019) 19:398-410. doi: 10.1038/s41577-019-0145-4

148. Pearce EL, Mullen AC, Martins GA, Krawczyk CM, Hutchins AS, Zediak VP, et al. Control of effector $\mathrm{CD}^{+} \mathrm{T}$ cell function by the transcription factor Eomesodermin. Science. (2003) 302:1041-3. doi: 10.1126/science.1090148

149. Banerjee A, Gordon SM, Intlekofer AM, Paley MA, Mooney EC, Lindsten T, et al. Cutting edge: the transcription factor eomesodermin enables $\mathrm{CD} 8^{+} \mathrm{T}$ cells to compete for the memory cell niche. J Immunol. (2010) 185:4988-92. doi: 10.4049/jimmunol.1002042

150. Staron MM, Gray SM, Marshall HD, Parish IA, Chen JH, Perry CJ, et al. The transcription factor FoxO1 sustains expression of the inhibitory receptor PD-1 and survival of antiviral CD8(+) T cells during chronic infection. Immunity. (2014) 41:802-14. doi: 10.1016/j.immuni.2014.10.013

151. Delpoux A, Lai CY, Hedrick SM, Doedens AL. FOXO1 opposition of CD8(+) T cell effector programming confers early memory properties and phenotypic diversity. Proc Natl Sci USA. (2017) 114:E8865-74. doi: 10.1073/pnas.1618916114

152. Shin H, Blackburn SD, Intlekofer AM, Kao C, Angelosanto JM, Reiner $\mathrm{SL}$, et al. A role for the transcriptional repressor Blimp-1 in CD8(+) T cell exhaustion during chronic viral infection. Immunity. (2009) 31:309-20. doi: 10.1016/j.immuni.2009.06.019

153. Man K, Gabriel SS, Liao Y, Gloury R, Preston S, Henstridge DC, et al. Transcription factor IRF4 promotes CD8(+) T cell exhaustion and limits the development of memory-like T cells during chronic infection. Immunity. (2017) 47:1129-41. doi: 10.1016/j.immuni.2017.11.021

154. Kurachi M, Barnitz RA, Yosef N, Odorizzi PM, DiIorio MA, Lemieux ME, et al. The transcription factor BATF operates as an essential differentiation checkpoint in early effector CD8 ${ }^{+}$T cells. Nat Immunol. (2014) 15:373-83. doi: $10.1038 /$ ni.2834

155. Zhu L, Kong Y, Zhang J, Claxton DF, Ehmann WC, Rybka WB, et al. Blimp-1 impairs T cell function via upregulation of TIGIT and PD-1 in patients with acute myeloid leukemia. J Hematol Oncol. (2017) 10:124. doi: 10.1186/s13045-017-0486-z

156. Haase VH. The VHL/HIF oxygen-sensing pathway and its relevance to kidney disease. Kidney Int. (2006) 69:1302-7. doi: 10.1038/sj.ki.5000221

157. Khan O, Giles JR, McDonald S, Manne S, Ngiow SF, Patel KP, et al. TOX transcriptionally and epigenetically programs CD8(+) T cell exhaustion. Nature. (2019) 571:211-8. doi: 10.1038/s41586-019-1325-x

158. Seo H, Chen J, Gonzalez-Avalos E, Samaniego-Castruita D, Das A, Wang YH, et al. TOX and TOX2 transcription factors cooperate with NR4A transcription factors to impose $\mathrm{CD} 8(+) \mathrm{T}$ cell exhaustion. Proc Natl Acad Sci USA. (2019) 116:12410-5. doi: 10.1073/pnas.19056 75116 
159. Wang X, He Q, Shen H, Xia A, Tian W, Yu W, et al. TOX promotes the exhaustion of antitumor $\mathrm{CD} 8^{+} \mathrm{T}$ cells by preventing PD1 degradation in hepatocellular carcinoma. J Hepatol. (2019). doi: 10.1016/j.jhep.2019.05.015. [Epub ahead of print].

160. Im SJ, Hashimoto M, Gerner MY, Lee J, Kissick HT, Burger MC, et al. Defining $\mathrm{CD}^{+} \mathrm{T}$ cells that provide the proliferative burst after PD-1 therapy. Nature. (2016) 537:417-21. doi: 10.1038/nature19330

161. Topalian SL, Hodi FS, Brahmer JR, Gettinger SN, Smith DC, McDermott DF, et al. Safety, activity, and immune correlates of anti-PD-1 antibody in cancer. N Engl J Med. (2012) 366:2443-54. doi: 10.1056/NEJMoa1200690

162. Hamid O, Robert C, Daud A, Hodi FS, Hwu WJ, Kefford R, et al. Safety and tumor responses with lambrolizumab (anti-PD-1) in melanoma. $N$ Engl J Med. (2013) 369:134-44. doi: 10.1056/NEJMoal305133

163. Ribas A, Wolchok JD. Cancer immunotherapy using checkpoint blockade. Science. (2018) 359:1350-5. doi: 10.1126/science.aar4060

164. Im A, Pavletic SZ. Immunotherapy in hematologic malignancies: past, present, and future. J Hematol Oncol. (2017) 10:94. doi: 10.1186/s13045-017-0453-8S

165. Krummel MF, Allison JP. CD28 and CTLA-4 have opposing effects on the response of T cells to stimulation. J Exp Med. (1995) 182:45965. doi: $10.1084 /$ jem.182.2.459

166. Sharpe AH, Pauken KE. The diverse functions of the PD1 inhibitory pathway. Nat Rev Immunol. (2018) 18:153-67. doi: 10.1038/nri.2017.108

167. Hodi FS, O'Day SJ, McDermott DF, Weber RW, Sosman JA, Haanen JB, et al. Improved survival with ipilimumab in patients with metastatic melanoma. $N$ Engl J Med. (2010) 363:711-23. doi: 10.1056/NEJMoa1003466

168. Robert C, Thomas L, Bondarenko I, O'Day S, Weber J, Garbe C, et al. Ipilimumab plus dacarbazine for previously untreated metastatic melanoma. N Engl J Med. (2011) 364:2517-26. doi: 10.1056/NEJMoa1104621S

169. Kvistborg P, Philips D, Kelderman S, Hageman L, Ottensmeier C, Joseph-Pietras D, et al. Anti-CTLA-4 therapy broadens the melanomareactive $\mathrm{CD}^{+} \mathrm{T}$ cell response. Sci Trans Med. (2014) 6:254ra128. doi: 10.1126/scitranslmed.3008918

170. Ansell SM, Lesokhin AM, Borrello I, Halwani A, Scott EC, Gutierrez M, et al. PD-1 blockade with nivolumab in relapsed or refractory Hodgkin's lymphoma. N Engl J Med. (2015) 372:311-9. doi: 10.1056/NEJMoa1411087

171. Nghiem PT, Bhatia S, Lipson EJ, Kudchadkar RR, Miller NJ, Annamalai L, et al. PD-1 Blockade with pembrolizumab in advanced merkel-cell carcinoma. N Engl J Med. (2016) 374:2542-52. doi: 10.1056/NEJMoa1603702

172. Le DT, Durham JN, Smith KN, Wang H, Bartlett BR, Aulakh LK, et al. Mismatch repair deficiency predicts response of solid tumors to PD-1 blockade. Science. (2017) 357:409-13. doi: 10.1126/science.aan6733

173. Eroglu Z, Zaretsky JM, Hu-Lieskovan S, Kim DW, Algazi A, Johnson DB, et al. High response rate to PD-1 blockade in desmoplastic melanomas. Nature. (2018) 553:347-50. doi: 10.1038/nature25187

174. Tang B, Yan X, Sheng X, Si L, Cui C, Kong Y, et al. Safety and clinical activity with an anti-PD-1 antibody JS001 in advanced melanoma or urologic cancer patients. J Hematol Oncol. (2019) 12:7. doi: 10.1186/s13045-018-0693-2

175. Xia $\mathrm{AL}, \mathrm{Xu} \quad \mathrm{Y}, \mathrm{Lu} \mathrm{XJ}$. Cancer immunotherapy: challenges and clinical applications. J Med Genet. (2019) 56:1-3. doi: 10.1136/jmedgenet-2018-105852

176. Wolchok JD, Kluger H, Callahan MK, Postow MA, Rizvi NA, Lesokhin AM, et al. Nivolumab plus ipilimumab in advanced melanoma. $N$ Engl J Med. (2013) 369:122-33. doi: 10.1056/NEJMoa1302369

177. Larkin J, Chiarion-Sileni V, Gonzalez R, Grob JJ, Cowey CL, Lao $\mathrm{CD}$, et al. Combined nivolumab and Ipilimumab or monotherapy in untreated melanoma. N Engl J Med. (2015) 373:23-34. doi: 10.1056/NEJMoa 1504030

178. Lu X, Yang L, Yao D, Wu X, Li J, Liu X, et al. Tumor antigen-specific CD8(+) $\mathrm{T}$ cells are negatively regulated by PD- 1 and Tim- 3 in human gastric cancer. Cell Immunol. (2017) 313:43-51. doi: 10.1016/j.cellimm.2017.01.001

179. Matsuzaki J, Gnjatic S, Mhawech-Fauceglia P, Beck A, Miller A, Tsuji T, et al. Tumor-infiltrating NY-ESO-1-specific $\mathrm{CD} 8^{+} \mathrm{T}$ cells are negatively regulated by LAG-3 and PD-1 in human ovarian cancer. Proc Natl Acad Sci USA. (2010) 107:7875-80. doi: 10.1073/pnas.1003345107

180. Pollok KE, Kim YJ, Zhou Z, Hurtado J, Kim KK, Pickard RT, et al. Inducible $\mathrm{T}$ cell antigen 4-1BB. Analysis of expression and function. J Immunol. (1993) 150:771-81.
181. Wei H, Zhao L, Li W, Fan K, Qian W, Hou S, et al. Combinatorial PD-1 blockade and CD137 activation has therapeutic efficacy in murine cancer models and synergizes with cisplatin. PLoS ONE. (2013) 8:e84927. doi: 10.1371/journal.pone.0084927

182. Chen S, Lee LF, Fisher TS, Jessen B, Elliott M, Evering W, et al. Combination of 4-1BB agonist and PD-1 antagonist promotes antitumor effector/memory CD8 T cells in a poorly immunogenic tumor model. Cancer Immunol Res. (2015) 3:149-60. doi: 10.1158/2326-6066.CIR14-0118

183. Croft M. Control of immunity by the TNFR-related molecule OX40 (CD134). Ann Rev Immunol. (2010) 28:57-78. doi: 10.1146/annurev-immunol-030409-101243

184. Kjaergaard J, Tanaka J, Kim JA, Rothchild K, Weinberg A, Shu S. Therapeutic efficacy of OX-40 receptor antibody depends on tumor immunogenicity and anatomic site of tumor growth. Cancer Res. (2000) 60:5514-21.

185. Weinberg AD, Rivera MM, Prell R, Morris A, Ramstad T, Vetto JT, et al. Engagement of the OX-40 receptor in vivo enhances antitumor immunity. $J$ Immunol. (2000) 164:2160-S9. doi: 10.4049/jimmunol.164.4.2160

186. Shrimali RK, Ahmad S, Verma V, Zeng P, Ananth S, Gaur P, et al. Concurrent PD-1 blockade negates the effects of OX40 agonist antibody in combination immunotherapy through inducing T-cell apoptosis. Cancer Immunol. Res. (2017) 5:755-66. doi: 10.1158/2326-6066.CIR-17-0292

187. Wu X, Li J, Connolly EM, Liao X, Ouyang J, Giobbie-Hurder A, et al. Combined anti-VEGF and anti-CTLA-4 therapy elicits humoral immunity to Galectin-1 which is associated with favorable clinical outcomes. Cancer Immunol Res. (2017) 5:446-54. doi: 10.1158/2326-6066.CIR-1 6-0385

188. Zhang Y, Kurupati R, Liu L, Zhou XY, Zhang G, Hudaihed A, et al. Enhancing $\mathrm{CD} 8(+) \mathrm{T}$ cell fatty acid catabolism within a metabolically challenging tumor microenvironment increases the efficacy of melanoma immunotherapy. Cancer Cell. (2017) 32:377-91. doi: 10.1016/j.ccell.2017.08.004

189. Newick K, O’Brien S, Moon E, Albelda SM. CAR T cell therapy for solid tumors. Annu Rev Med. (2017) 68:139-52. doi: 10.1146/annurev-med-062315-120245

190. Garber K. Driving T-cell immunotherapy to solid tumors. Nat Biotechnol. (2018) 36:215-9. doi: 10.1038/nbt.4090

191. Wei G, Ding L, Wang J, Hu Y, Huang H. Advances of CD19-directed chimeric antigen receptor-modified $\mathrm{T}$ cells in refractory/relapsed acute lymphoblastic leukemia. Exp Hematol Oncol. (2017) 6:10. doi: 10.1186/s40164-017-0070-9

192. Cao J, Wang G, Cheng H, Wei C, Qi K, Sang W, et al. Potent anti-leukemia activities of humanized CD19-targeted chimeric antigen receptor T (CAR-T) cells in patients with relapsed/refractory acute lymphoblastic leukemia. Am J Hematol. (2018) 93:851-8. doi: 10.1002/ajh.25108

193. Fraietta JA, Lacey SF, Orlando EJ, Pruteanu-Malinici I, Gohil M, Lundh S, et al. Determinants of response and resistance to CD19 chimeric antigen receptor (CAR) T cell therapy of chronic lymphocytic leukemia. Nat Med. (2018) 24:563-71. doi: 10.1038/s41591-018-0010-1

194. Zolov SN, Rietberg SP, Bonifant CL. Programmed cell death protein 1 activation preferentially inhibits CD28.CAR-T cells. Cytotherapy. (2018) 20:1259-66. doi: 10.1016/j.jcyt.2018.07.005

195. Rafiq S, Yeku OO, Jackson HJ, Purdon TJ, van Leeuwen DG, Drakes DJ, et al. Targeted delivery of a PD-1-blocking scFv by CAR-T cells enhances anti-tumor efficacy in vivo. Nat Biotechnol. (2018) 36:847-56. doi: 10.1038/nbt.4195

196. Rupp LJ, Schumann K, Roybal KT, Gate RE, Ye CJ, Lim WA, et al. CRISPR/Cas9-mediated PD-1 disruption enhances anti-tumor efficacy of human chimeric antigen receptor T cells. Sci Rep. (2017) 7:737. doi: 10.1038/s41598-017-00462-8

197. Zhang Y, Zhang X, Cheng C, Mu W, Liu X, Li N, et al. CRISPR-Cas9 mediated LAG-3 disruption in CAR-T cells. Front Med. (2017) 11:554-62. doi: 10.1007/s11684-017-0543-6

198. Hu B, Zou Y, Zhang L, Tang J, Niedermann G, Firat E, et al. Nucleofection with plasmid DNA for CRISPR/Cas9-mediated inactivation of programmed cell death protein 1 in CD133-specific CAR T cells. Hum Gene Ther. (2018) 30: 446-458. doi: 10.1089/hum.2017.234

199. Li S, Siriwon N, Zhang X, Yang S, Jin T, He F, et al. Enhanced cancer immunotherapy by chimeric antigen receptor-modified $\mathrm{T}$ cells engineered 
to secrete checkpoint inhibitors. Clin Cancer Res. (2017) 23:6982-92. doi: 10.1158/1078-0432.CCR-17-0867

200. Suarez ER, Chang de K, Sun J, Sui J, Freeman GJ, Signoretti S, et al. Chimeric antigen receptor $\mathrm{T}$ cells secreting anti-PD-L1 antibodies more effectively regress renal cell carcinoma in a humanized mouse model. Oncotarget. (2016) 7:34341-55. doi: 10.18632/oncotarget.9114

201. Yoon DH, Osborn MJ, Tolar J, Kim CJ. Incorporation of immune checkpoint blockade into chimeric antigen receptor $\mathrm{T}$ cells (CAR-Ts): combination or built-in CAR-T. Int J Mol Sci. (2018) 19:340. doi: 10.3390/ijms19020340

202. Huang Q, Xia J, Wang L, Wang X, Ma X, Deng Q, et al. miR-153 suppresses IDO1 expression and enhances CAR T cell immunotherapy. J Hematol Oncol. (2018) 11:58. doi: 10.1186/s13045-018-0600-x

203. Beavis PA, Henderson MA, Giuffrida L, Mills JK, Sek K, Cross RS, et al. Targeting the adenosine $2 \mathrm{~A}$ receptor enhances chimeric antigen receptor T cell efficacy. J Clin Invest. (2017) 127:929-41. doi: 10.1172/JCI 89455

204. Wu X, Giobbie-Hurder A, Connolly EM, Li J, Liao X, Severgnini M, et al. Anti-CTLA-4 based therapy elicits humoral immunity to galectin-3 in patients with metastatic melanoma. Oncoimmunology. (2018) 7:e1440930. doi: 10.1080/2162402X.2018.1440930

205. Chinnasamy D, Yu Z, Kerkar SP, Zhang L, Morgan RA, Restifo NP, et al. Local delivery of interleukin-12 using T cells targeting VEGF receptor-2 eradicates multiple vascularized tumors in mice. Clin Cancer Res. (2012) 18:1672-83. doi: 10.1158/1078-0432.CCR-11-3050

206. Zaretsky JM, Garcia-Diaz A, Shin DS, Escuin-Ordinas H, Hugo W, Hu-Lieskovan S, et al. Mutations associated with acquired resistance to PD-1 blockade in melanoma. N Engl J Med. (2016) 375:819-29. doi: 10.1056/NEJMoa1604958

207. Patel SJ, Sanjana NE, Kishton RJ, Eidizadeh A, Vodnala SK, Cam M, et al. Identification of essential genes for cancer immunotherapy. Nature. (2017) 548:537-42. doi: 10.1038/nature23477
208. Hugo W, Shi H, Sun L, Piva M, Song C, Kong X, et al. Non-genomic and immune evolution of melanoma acquiring MAPKi resistance. Cell. (2015) 162:1271-85. doi: 10.1016/j.cell.2015.07.061

209. Ma C, Cheung AF, Chodon T, Koya RC, Wu Z, Ng C, et al. Multifunctional T-cell analyses to study response and progression in adoptive cell transfer immunotherapy. Cancer Discov. (2013) 3:418-29. doi: 10.1158/2159-8290.CD-12-0383

210. Efremova M, Rieder D, Klepsch V, Charoentong P, Finotello F, Hackl $\mathrm{H}$, et al. Targeting immune checkpoints potentiates immunoediting and changes the dynamics of tumor evolution. Nat Commun. (2018) 9:32. doi: 10.1038/s41467-017-02424-0

211. Shayan G, Srivastava R, Li J, Schmitt N, Kane LP, Ferris RL. Adaptive resistance to anti-PD1 therapy by Tim-3 upregulation is mediated by the PI3K-Akt pathway in head and neck cancer. Oncoimmunology. (2017) 6:e1261779. doi: 10.1080/2162402X.2016.1261779

212. Koyama S, Akbay EA, Li YY, Herter-Sprie GS, Buczkowski KA, Richards WG, et al. Adaptive resistance to therapeutic PD-1 blockade is associated with upregulation of alternative immune checkpoints. Nat Commun. (2016) 7:10501. doi: 10.1038/ncomms10501S

Conflict of Interest Statement: The authors declare that the research was conducted in the absence of any commercial or financial relationships that could be construed as a potential conflict of interest.

Copyright (๑) 2019 Xia, Zhang, Xu, Yin and Lu. This is an open-access article distributed under the terms of the Creative Commons Attribution License (CC BY). The use, distribution or reproduction in other forums is permitted, provided the original author(s) and the copyright owner(s) are credited and that the original publication in this journal is cited, in accordance with accepted academic practice. No use, distribution or reproduction is permitted which does not comply with these terms. 